\title{
Review \\ Uteroplacental Circulation in Normal Pregnancy and Preeclampsia: Functional Adaptation and Maladaptation
}

\author{
Xiangqun $\mathrm{Hu} *$ (i) and Lubo Zhang *(1) \\ Lawrence D. Longo, MD Center for Perinatal Biology, Department of Basic Sciences, School of Medicine, \\ Loma Linda University, Loma Linda, CA 92350, USA \\ * Correspondence: xhu@llu.edu (X.H.); lzhang@llu.edu (L.Z.)
}

check for updates

Citation: $\mathrm{Hu}, \mathrm{X}$; Z Zhang, L.

Uteroplacental Circulation in Normal

Pregnancy and Preeclampsia:

Functional Adaptation and

Maladaptation. Int. J. Mol. Sci. 2021,

22, 8622. https://doi.org/10.3390/

ijms22168622

Academic Editors: Nihar

Ranjan Nayak and David

K. Stevenson

Received: 26 July 2021

Accepted: 9 August 2021

Published: 11 August 2021

Publisher's Note: MDPI stays neutral with regard to jurisdictional claims in published maps and institutional affiliations.

Copyright: (c) 2021 by the authors. Licensee MDPI, Basel, Switzerland. This article is an open access article distributed under the terms and conditions of the Creative Commons Attribution (CC BY) license (https:// creativecommons.org/licenses/by/ $4.0 /)$.

\begin{abstract}
Uteroplacental blood flow increases as pregnancy advances. Adequate supply of nutrients and oxygen carried by uteroplacental blood flow is essential for the well-being of the mother and growth/development of the fetus. The uteroplacental hemodynamic change is accomplished primarily through uterine vascular adaptation, involving hormonal regulation of myogenic tone, vasoreactivity, release of vasoactive factors and others, in addition to the remodeling of spiral arteries. In preeclampsia, hormonal and angiogenic imbalance, proinflammatory cytokines and autoantibodies cause dysfunction of both endothelium and vascular smooth muscle cells of the uteroplacental vasculature. Consequently, the vascular dysfunction leads to increased vascular resistance and reduced blood flow in the uteroplacental circulation. In this article, the (mal)adaptation of uteroplacental vascular function in normal pregnancy and preeclampsia and underlying mechanisms are reviewed.
\end{abstract}

Keywords: pregnancy; preeclampsia; uteroplacental circulation; adaptation; endothelium; vascular smooth muscle

\section{Introduction}

Pregnancy starts from conception and ends with birth. Upon the completion of embryonic development, approximately at the end of 10 weeks of gestation, the fetus begins to grow and develop in utero [1]. The demand of nutrients and oxygen for fetal growth and development increases as pregnancy progresses, which is met by increased blood perfusion of the placenta. Depending on the species, uteroplacental blood flow at term increases 10-100-fold over nonpregnant levels [2]. To accommodate the dramatic change in uteroplacental hemodynamics, the maternal cardiovascular system undergoes physiological adaptation, as evidenced by increased plasma volume and cardiac output and decreased mean arterial blood pressure [3-5]. More importantly, dramatic changes occur locally. Uteroplacental circulation, which links the maternal circulation and fetal circulation, is established at the beginning of the second trimester [6,7]. The remodeling of spiral arteries and the functional adaptation of uterine arteries enable the uteroplacental circulation to become a low-resistance, high-flow system. Appropriate uteroplacental blood flow is pivotal for both fetal growth and maternal well-being $[8,9]$. Failure in the uteroplacental vascular transformation/adaptation is associated with pregnancy complications such as preeclampsia and fetal growth restriction [10-12]. Preeclampsia is characterized by new onset hypertension (systolic $>140 \mathrm{mmHg}$ and diastolic $>90 \mathrm{mmHg}$ ) after 20 weeks' gestation with one or more of the following features: proteinuria, other maternal organ dysfunction such as acute kidney injury, liver dysfunction, neurological complications and hematological complications and fetal growth restriction [13-15]. It affects 5-10\% of pregnancies worldwide with high maternal and perinatal morbidity and mortality [12]. It also predisposes long-term health risks, especially cardiovascular and metabolic disease for the mother and child [16-19]. The remodeling of spiral arteries has been reviewed elsewhere [2,20]. Preeclampsia is a spontaneous pregnancy complication unique to humans [21]. However, 
due to ethical concerns and scarcity in human specimens, our understanding of the pathogenesis of preeclampsia largely relies on findings from animal models of preeclampsia induced by surgical, environmental, pharmacological, immunological or genetic manipulation before or during pregnancy which recapitulate some features of this disorder [22]. This review intends to summarize our knowledge on the functional (mal)adaptation of uteroplacental circulation in normal pregnancy and preeclampsia. To achieve this aim, relevant publications involving both human and animal model studies primarily in the past three decades were searched in PubMed and synthesized.

\section{Uteroplacental Vascular (Mal)Adaptation in Normal Pregnancy and Preeclampsia}

As uterine vascular resistance decreases, uterine blood flow increases to $\sim 800 \mathrm{~mL} / \mathrm{min}$ in late human pregnancy, from $\sim 50 \mathrm{~mL} / \mathrm{min}$ in nonpregnant subjects [23-26]. Studies in experimental animals such as sheep, guinea pigs and rats reveal that more than $80 \%$ of uterine blood flow perfuses the placenta [27-29]. In contrast, uterine vascular resistance is increased in preeclampsia compared to normal pregnancy, resulting in a $50 \%$ decrease in uterine blood flow [30-32]. High-altitude pregnancy is associated with a $~ 3-$ fold increase in the incidence of preeclampsia [33,34]. A decrease in uterine blood flow is also observed in pregnant women at high altitude [35].

In a given organ, vascular tone is largely determined by (1) intrinsic myogenic regulation; (2) the dynamics of vasoconstrictor and vasodilator influences acting on the vasculature; and (3) flow- or shear-stress-mediated regulation (Figure 1) [36]. Neurohumoral and metabolic factors also contribute to the regulation of vascular tone. Any change in these regulations could alter vascular resistance and hence blood flow to an organ. The altered uteroplacental hemodynamics in both normal pregnancy and preeclampsia is in part the consequence of functional (mal)adaptation of the uteroplacental vasculature involving both the endothelium and vascular smooth muscle.

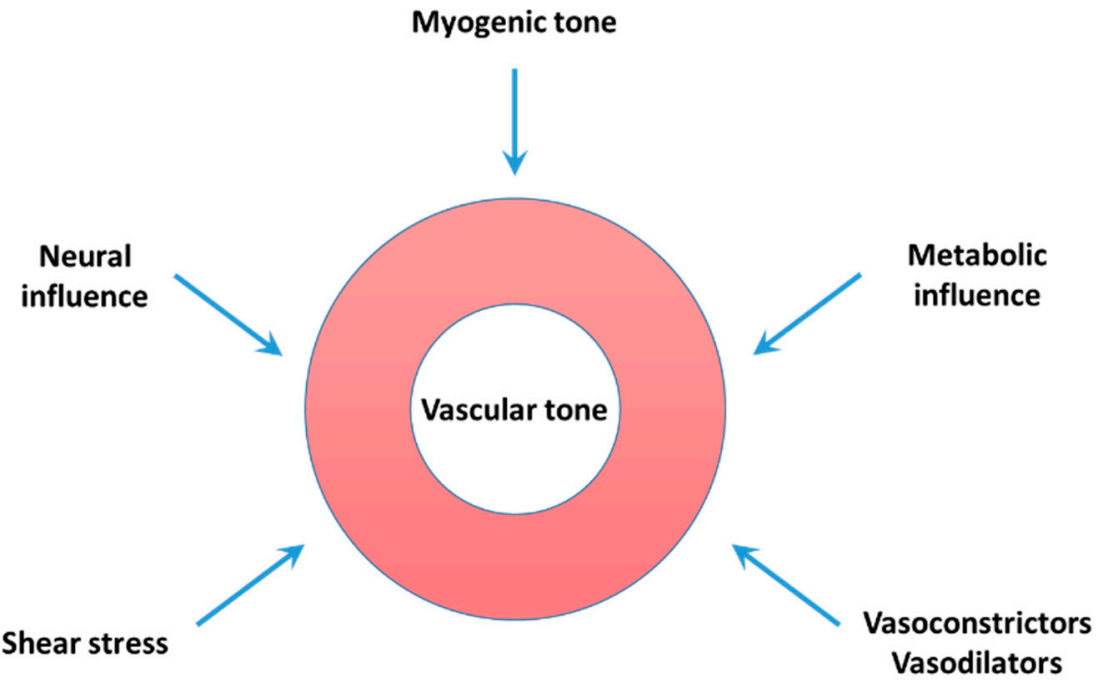

Figure 1. Vascular tone is determined by a variety of factors. Myogenic tone produced in response to intraluminal pressure changes constitutes the basal vascular tone, upon which vasoconstrictors, vasodilators and neurotransmitters released by sympathetic and parasympathetic nerves, locally produced metabolic substances and others can act to produce vasoconstriction or vasodilation.

\subsection{Myogenic Tone}

The smooth muscles of resistance arteries and arterioles possess pressure-dependent reactivity (myogenic response) [37]. They constrict upon an increase in intraluminal pressure and dilate in response to a decrease in this pressure. Myogenic tone constitutes the foundation of vascular tone and is modulated by vasodilators and vasoconstrictors, as well as other vasoactive factors. Thus, myogenic tone plays a critical role in regulating blood pressure and tissue/organ perfusion [38]. Altered uterine arterial myogenic tone 
may impact uteroplacental blood flow and the perfusion of the placenta. To accommodate markedly increased uterine blood flow, reduced myogenic tone of uterine arteries is desirable. Indeed, uterine arterial myogenic tone is decreased in pregnant mice $[39,40]$. Similarly, pregnancy-induced attenuation of myogenic tone is observed in sheep, which contributes to reduced uterine vascular tone in ovine pregnancy [41,42]. Unexpectedly, pregnancy increases uterine arterial myogenic tone in human myometrial arteries and rat radial arteries [43,44]. Intriguingly, myometrial arteries from women with preeclampsia and normal pregnancy display similar myogenic tone [45]. It should be noted that myogenic tone in myometrial arteries from preeclamptic patients is only measured at a single pressure point $(80 \mathrm{~mm} \mathrm{Hg})$. Nevertheless, uterine arterial myogenic tone is increased in a rat model of preeclampsia with surgically reduced uterine perfusion pressure (RUPP) [46]. Pregnancy at high altitude is associated with increased incidence of preeclampsia [33]. Uterine arterioles from pregnant sheep at high altitude also exhibit increased myogenic tone $[47,48]$.

\subsection{Vasoreactivity}

Pregnancy also alters the vascular reactivity of uterine arteries. Vasodilation mediated by acetylcholine and bradykinin usually requires an intact and functioning endothelium [49]. As expected, endothelium-dependent relaxation of uterine arteries in response to acetylcholine and bradykinin, as well as other compounds, is increased in pregnancy [50-54]. Pregnancy also enhances calcitonin gene-related peptide- and adrenomedullin-induced relaxation of uterine arteries [55,56]. On the other hand, uterine arteries from human and experimental animals become refractory to various vasopressors, including angiotensin II, endothelin, neuropeptide $Y$, norepinephrine, epinephrine, phenylephrine and serotonin, during pregnancy [57-63]. Together, these alterations may contribute to reduced uteroplacental vascular resistance in pregnancy. Apparently, the pregnancy-induced changes in uterine arterial vasoreactivity are diminished in preeclampsia. Endothelium-dependent relaxation of myometrial arteries from preeclamptic women in response to acetylcholine and bradykinin as well as other compounds is reduced [64-73]. Uterine arteries from pregnant rats exposed to chronic hypoxia also display impaired endothelium-dependent relaxation [74]. Prolonged hypoxia exposure increases uterine vascular resistance in pregnant guinea pigs [75]. In rat models of preeclampsia, induced by crossing females overexpressing human angiotensinogen with males overexpressing human renin (TgA) and by RUPP, uterine arteries exhibit both enhanced contraction to phenylephrine and repressed relaxation to acetylcholine [76,77]. Uterine arteries from $\operatorname{TgA}$ rats also show increased maximal contraction and sensitivity to angiotensin II [78].

\subsection{Shear Stress}

Shear stress is the frictional force on the endothelium in vasculature exerted by blood flow. Shear stress plays an important role in regulating vascular tone, angiogenesis, and vascular remodeling [79]. Shear stress is sensed by the endothelium, leading to increased release of vasodilators. In response to shear stress, the acute vascular response in peripheral circulation is vasodilation [80]. Vasodilation of uterine arteries from guinea pigs in response to shear stress increases in pregnancy [81]. NO is the major mediator of shear stress/flowinduced vasodilation of uterine arteries [45,81]. However, flow-mediated vasodilation of myometrial arteries is diminished in preeclampsia [45]. Furthermore, shear stress promotes vasoconstriction in uterine arteries of guinea pigs exposed to gestational hypoxia [81].

\subsection{Release of Endothelium-Derived Vasodilators}

Endothelial cells release various vasodilators to regulate vascular tone [82]. Notably, among them are nitric oxide (NO), prostacyclin $\left(\mathrm{PGI}_{2}\right)$ and hydrogen sulfide $\left(\mathrm{H}_{2} \mathrm{~S}\right)$, which are enzymatic products of endothelial NO synthase (eNOS), phospholipase $\mathrm{A}_{2}$ $\left(\mathrm{PLA}_{2}\right) /$ cyclooxygenases (COXs) / prostacyclin synthase (PGIS) and cystathionine $\beta$-synthase (CBS) / cystathionine- $\gamma$-lyase (CSE), respectively. NO produces vasodilation by stimulat- 
ing soluble guanylate cyclase, leading to an increase in cyclic guanosine monophosphate (cGMP) [83]. Classically, $\mathrm{PGI}_{2}$ exerts its vasodilation through activating $\mathrm{PGI}_{2}$ receptor coupled to the $G \alpha$ s protein-adenylyl cyclase pathway to produce cyclic adenosine monophosphate (cAMP) $[84,85]$. The mechanism underlying $\mathrm{H}_{2} \mathrm{~S}$-induced vasodilation remains not fully understood, potentially involving activation of $\mathrm{K}^{+}$channels [86]. In addition, endothelium-derived hyperpolarizing factor (EDHF) is also released by endothelial cells. EDHF plays an important role in the regulation of vascular tone mediated by the opening of $\mathrm{Ca}^{2+}$-activated $\mathrm{K}^{+}$channels of small $\left(\mathrm{SK}_{\mathrm{Ca}}\right.$ or $\left.\mathrm{K}_{\mathrm{Ca}} 2.3\right)$ and intermediate $\left(\mathrm{IK}_{\mathrm{Ca}}\right.$ or $\mathrm{K}_{\mathrm{Ca}} 3.1$ ) conductance and myoendothelial gap junctions (MEGJs) and potassium efflux, among others $[87,88]$. These factors are involved in uterine vascular adaptation in normal pregnancy, whereas their abnormal production is associated with preeclampsia [89-93].

eNOS converts its substrate L-arginine to L-citrulline and NO, producing most vascular NO. NO plays a pivotal role in uterine vascular (mal)adaptation in pregnancy and preeclampsia $[93,94]$. The expression and activity of eNOS in endothelial cells of human and ovine uterine arteries are augmented in pregnancy [95-97]. Associated with eNOS upregulation is the increased production/release of $\mathrm{NO}$ in uterine arteries $[95,98,99]$. Uterine vascular resistance reduces following administration of the NO donor isosorbide dinitrate in pregnant women [100]. Pregnancy enhances the NOS inhibitor $\mathrm{N}^{\omega}{ }^{\omega}$-nitro-L-arginine methyl ester (L-NAME)-induced constriction of rat uterine arteries [50]. Consistently, a local infusion of L-NAME into uterine arteries reduces basal uterine blood flow in pregnant but not in nonpregnant sheep [101-103]. Pregnancy-mediated enhancement of endothelium-dependent relaxation and refractoriness to vasoconstrictors in uterine arteries and estrogen-induced increase in uterine blood flow are in part mediated by NO [50,54,99,104-107]. Furthermore, eNOS deficiency attenuates acetylcholine-induced endothelium-dependent relaxation of uterine arteries, increases uterine vascular resistance and reduces uterine blood flow in pregnant mice [108-111]. The expression and activity of eNOS in uteroplacental tissues in preeclampsia remain controversial and both increased [112,113] or decreased [114-118] expression have been documented. Chronic exposure of endothelial cells to plasma from preeclamptic patients results in increased expression/activity of eNOS [119,120]. Similarly, rat uterine arteries exposed to plasma from women with preeclampsia show an increase in eNOS expression [121]. Uterine arteries from high-altitude pregnant sheep also display upregulated eNOS [96]. However, NO bioavailability is diminished in preeclampsia $[93,122]$. The reduced NO bioavailability in preeclampsia is probably caused by (1) NO reacting with superoxide $\left(\mathrm{O}_{2}{ }^{\bullet-}\right)$ to produces peroxynitrite $\mathrm{ONOO}^{-}$, (2) uncoupling of eNOS, (3) substrate deficiency and (4) enzyme inhibition [114,123-127]. Consequently, preeclampsia diminishes shear-stress induced NO release and decreases NO-mediated dilatation in myometrial arteries [45,68]. Similarly, NO-dependent relaxation of myometrial arteries from high-altitude pregnancy is reduced [128].

CBS and CSE are two key enzymes in the synthesis of $\mathrm{H}_{2} \mathrm{~S}$ from cysteine or homocysteine. In a way similar to $\mathrm{NO}, \mathrm{H}_{2} \mathrm{~S}$ is an important cardiovascular signaling molecule and contributes to the regulation of vascular tone [129]. Pregnancy promotes the expression of CBS and $\mathrm{H}_{2} \mathrm{~S}$ production in both endothelial cells and smooth muscle cells of uterine arteries [130,131]. $\mathrm{H}_{2} \mathrm{~S}$-induced relaxation of human uterine arteries is increased in pregnancy [130]. $\mathrm{E}_{2} \beta$-stimulated increases in uterine blood flow, but not basal uterine flood flow, are diminished in CSE knockout mice [132]. $\mathrm{H}_{2} \mathrm{~S}$ also relaxes placental vessels [133]. Placental expression of CBS and CSE is reduced in preeclampsia [133-135]. CSE expression in the placenta is also decreased in the preeclampsia model of RUPP mice [136]. Notably, siRNA knockdown of CSE in human umbilical vein endothelial cells (HUVECs) promotes the release of soluble fms-like tyrosine kinase-1 (sFlt-1) and soluble endoglin [135].

$\mathrm{PGI}_{2}$ is synthesized from arachidonic acid via enzymatic actions of $\mathrm{PLA}_{2}, \mathrm{COXs}$ and PGIS. The expression of these enzymes and production of $\mathrm{PGI}_{2}$ are increased in uterine arteries in pregnancy [137-140]. Infusion of $\mathrm{PGI}_{2}$ into uterine arteries increases uterine blood flow in pregnant dogs [141]. Although administration of the PGIS inhibitor 
tranylcypromine results in a reduction in uterine blood flow in pregnant sheep, the resultant uterine vascular constriction is apparently not due to reduced $\mathrm{PGI}_{2}$ production [142] Placental COX1/2 expression is reduced in preeclampsia [143-145]. Correspondingly, $\mathrm{PGI}_{2}$ production is decreased, leading to a higher prostacyclin/thromboxane A2 ratio [146-148]. The level of 6-keto-PGF1 $\alpha$ (a stable metabolite of prostacyclin) in omental resistance arteries is lower in preeclampsia than in normal pregnancy [149]. These findings imply a reduced role of $\mathrm{PGI}_{2}$ in regulating uterine vascular tone in preeclampsia.

Pregnancy enhances EDHF-mediated vasodilation of rat uterine arteries [150,151]. Myoendothelial gap junctions (MEGJs), formed by the assembly of connexins, connect endothelial cells and juxtaposed vascular smooth muscle cells to make them electrically coupled. An increase in intracellular $\mathrm{Ca}^{2+}$ in endothelial cells activates $\mathrm{IK}_{\mathrm{Ca}}$ and $\mathrm{SK}_{\mathrm{Ca}}$, leading to hyperpolarization. MEGJs enable endothelial cell hyperpolarization to be directly transmitted to vascular smooth muscle cells to cause subsequent vasorelaxation [152]. EDHF through MEGJs appears to be the major mediator of endothelium-dependent relaxation of myometrial arteries in pregnancy, which is impaired in preeclampsia $[71,153,154]$. SK $\mathrm{Ca}$ channel expression and $\mathrm{SK}_{\mathrm{Ca}}$ channel-mediated relaxation of uterine arteries are suppressed in high-altitude pregnant sheep [155]. The expression of $\mathrm{IK}_{\mathrm{Ca}}$ and $\mathrm{SK}_{\mathrm{Ca}}$ channels in placental chorionic plate arteries is downregulated in preeclampsia, leading to impaired $\mathrm{IK}_{\mathrm{Ca}}{ }^{-}$ and $\mathrm{SK}_{\mathrm{Ca}}$-mediated vasorelaxation [117]. The expression of $\mathrm{SK}_{\mathrm{Ca}}$ channels in HUVECs is also reduced in preeclampsia [156]. Exposing human uterine microvascular endothelial cells and HUVECs to plasma from preeclamptic patients also causes downregulation of the $\mathrm{SK}_{\mathrm{Ca}}$ channel [156]. This downregulation is mediated by NOX2-derived superoxide.

\section{Mechanisms Underlying Uterine Vascular (Mal)Adaptation in Normal Pregnancy and Preeclampsia}

\subsection{The Estrogen-ER Signaling Pathway}

Circulating estrogen level increases progressively and substantially during pregnancy [157]. Estrogen is a key player in regulating uteroplacental vascular function, leading to reduced uterine vascular resistance/increased uterine blood flow in pregnancy [158-162]. Direct evidence of regulation of uterine blood flow by estrogen comes from observations that infusion of the non-selective estrogen receptor inhibitor ICI 182, 780 into the uterine artery reduces basal uterine blood flow in pregnant sheep and that both acute and chronic administration of estradiol-17 $\beta\left(E_{2} \beta\right)$ increase uterine blood flow in ovariectomized nonpregnant sheep [163-165]. The reduction in exogenous and endogenous estrogen-induced increase in uterine blood flow by ICI 182, 780 suggests the involvement of estrogen receptors (ERs) [165]. Not surprisingly, activation of either ER $\alpha$ or ER $\beta$ relaxes both human myometrial and placental arteries [166]. G-protein-coupled estrogen receptor (GPER, also known as G-protein-coupled receptor 30 (GPR30)) is expressed in rat uterine arteries and its expression is increased in pregnancy [167]. Consistently, pregnancy enhances the relaxation of rat uterine arteries mediated by GPER [167]. However, this mechanism seems not to occur in human uteroplacental vessels, as the selective GPER agonist G1 fails to relax both myometrial and placental arteries [166]. Estrogen also induces ER-independent relaxation of rat uterine arteries [168]. The estrogen effects on the endothelium and vascular smooth muscle of uteroplacental vessels are evidently mediated by impacting multiple signaling pathways, as discussed below.

The placenta is the primary source of estrogen during pregnancy [169]. Preeclamptic patients have lower placental and plasma estrogen compared to the counterparts of normal pregnancy [169-172]. Similarly, high-altitude pregnancy also displays lower circulating estrogen $[173,174]$. Deficiency of aromatase in the preeclamptic placentas has been shown to account for the reduced biosynthesis of estrogen $[175,176]$. Hypoxia apparently mediates the downregulation of aromatase in the placenta $[176,177]$. In addition, elevated ROS in preeclamptic placentas also suppresses estrogen biosynthesis [172]. The aberrant estrogen production in turn disrupts the $E_{2} \beta$-ER signaling pathway and plays an important role in the pathogenesis of preeclampsia [161,169]. 
Estrogen exerts its regulatory actions by binding to multiple ERs, including classical nuclear ER $\alpha$ and ER $\beta$ as well as membrane GPER [178]. Estrogen generally stimulates its target genes, including its own expression by (1) ligand-activated ER binding to the estrogen response element (ERE) in the target gene, and (2) ligand-activated ER tethering with the other transcription factors. ER expression in uterine arteries is regulated by estrogen status. Both ER $\alpha$ and ER $\beta$ are expressed in human and ovine uterine arteries and their expression is increased in pregnancy $[166,179,180]$. Their upregulation in pregnancy is stimulated by estrogen, as it is replicated by $\mathrm{E}_{2} \beta$ administration in ovariectomized nonpregnant sheep and rats and by ex vivo $\mathrm{E}_{2} \beta$ treatment of uterine arteries from nonpregnant ewes [179-181]. A half ERE consensus-binding site is located in the ESR1 promoter [182] and its role in regulating ER expression in uterine arteries remains unexplored. It appears that the second mechanism is responsible for the upregulation of ER $\alpha$ in ovine uterine arteries in pregnancy. A study from the Zhang lab demonstrates that both ER $\alpha$ and ER $\beta$ could tether with Sp1 at the Sp1 $1^{-520}$-binding site in the promoter of the Er $\alpha$-encoding gene ESR1 to regulate ER $\alpha$ expression in ovine uterine arteries [183]. The Sp1 $1^{-520}$-binding site is hypermethylated in the nonpregnant status, preventing Er $\alpha-\mathrm{SP} 1$ binding to the Sp1 binding site. Pregnancy promotes the demethylation of the site, leading to increased $\mathrm{ER} \alpha$ expression in uterine arteries, which is probably due to the estrogen-mediated upregulation of ten-eleven translocation methylcytosine dioxygenase 1 (TET1), an enzyme catalyzing active demethylation [184]. The expression of ESR1 is reduced in preeclamptic placentas, whereas the placental expression of $\operatorname{Er} \beta$-encoding gene ESR2 is upregulated in preeclampsia $[185,186]$. The downregulation of ESR1 is induced by exposing human placenta-derived BeWo cells to hypoxia [185]. Similarly, the expression of ESR1 in ovine uterine arteries is also reduced in high-altitude pregnancy as the result of hypoxia $[181,183]$. Hypoxia upregulates DNA methyltransferase 3b (DNMT3b) and downregulates TET1, leading to ESR1 promoter hypermethylation and subsequent downregulation of ESR1 in uterine arteries of pregnant sheep [187-189]. $E_{2} \beta$ stimulates GPER expression in HTR8/SVneo cells [190]. The expression of GPER is also reduced in preeclamptic placenta [190].

eNOS is a downstream signal of the estrogen-ER signaling pathway. Acute estrogen exposure stimulates NO production/release from endothelial cells of ovine uterine arteries by regulating stimulatory and inhibitory phosphorylation sites of eNOS [191]. Activation of $\mathrm{ER} \alpha$ increases phosphorylation in $\mathrm{eNOS}^{\mathrm{Ser} 1177}$ and $\mathrm{eNOS}^{\mathrm{Ser} 635}$ and decreases phosphorylation in eNOSThr495, whereas activation of ER $\beta$ only reduces phosphorylation in eNOSThr495. Chronic treatment with $E_{2} \beta$ in ovariectomized nonpregnant sheep increases eNOS expression in the endothelium of uterine arteries through transcriptional regulation [192-194]. In HUVEC, $E_{2} \beta$-induced upregulation of eNOS is mediated by ER $\alpha$ [195] (Figure 2). The upregulation of CBS is evidently mediated by the $\mathrm{E}_{2} \beta$-ER signaling pathway (Figure 2). Administrating $E_{2} \beta$ into ovariectomized nonpregnant sheep promotes CBS expression in both endothelial cells and vascular smooth muscle cells of uterine arteries [196]. Moreover, the upregulation of CBS by $E_{2} \beta$ is blocked by ICI 182, 780 in cultured uterine artery endothelial cells and smooth muscle cells $[197,198]$. Exposure of villus explants to hypoxiareoxygenation upregulates miR-21, which in turn downregulates CSE [133]. $E_{2} \beta$ is also found to stimulate COX-1 and PGIS through ER $\alpha$ in HUVECs and ovine uterine artery endothelial cells, leading to increased $\mathrm{PGI}_{2}$ production $[199,200]$ (Figure 2). EDHF-mediated vasodilation of uterine arteries is also subject to $E_{2} \beta$ modulation. $E_{2} \beta$ replacement in ovariectomized nonpregnant rats increases EDHF-mediated vasodilation of uterine arteries via increasing $\mathrm{Ca}^{2+}$ signal in endothelial cells [201]. Consistently, the expression of $\mathrm{SK}_{\mathrm{Ca}}$ channels in ovine uterine arteries is upregulated by $E_{2} \beta$ [155]. Pregnancy also through the $\mathrm{E}_{2} \beta$-ER $\beta$ pathway upregulates the expression of angiotensin II type $2\left(\mathrm{AT}_{2}\right)$ receptor in the endothelium of human and rat uterine arteries, leading to increased uterine blood flow in rats [202,203]. Evidently, the dysfunction of estrogen biosynthesis can have great impacts on the expression/activity of eNOS, CBS/CSE, COXs/PGI, SK $\mathrm{Ca}_{\mathrm{a}}$ channels and $\mathrm{AT}_{2}$ receptors in uteroplacental vessels. Estrogen also regulates other signal pathways, which is discussed below. 


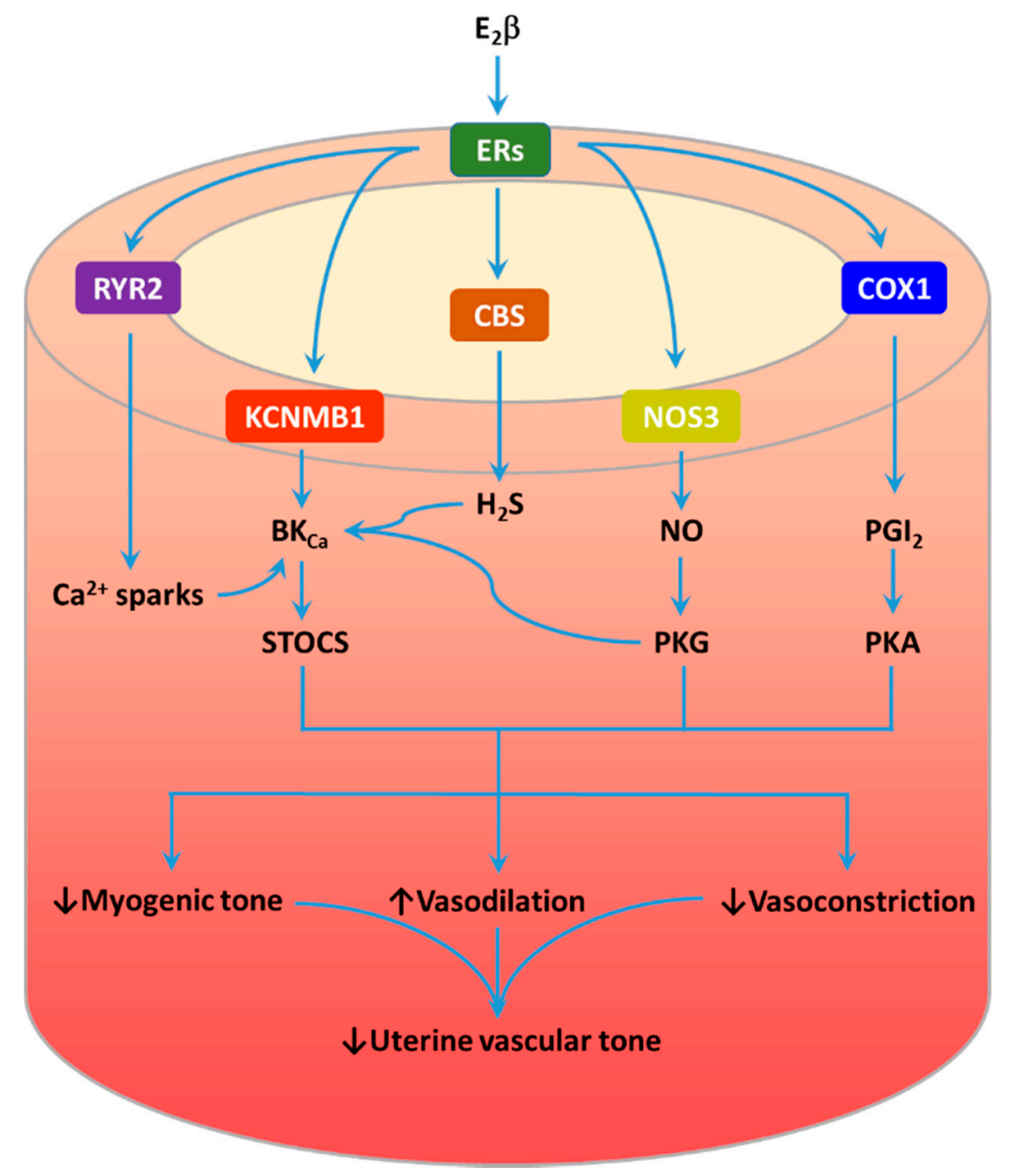

Figure 2. Estrogen plays a pivotal role in regulating functional adaptation of uteroplacental vessels in pregnancy. $17 \beta$-Estradiol $\left(E_{2} \beta\right)$ upregulates RYR2 and KCNMB1 expression and ryanodine receptor $2\left(\mathrm{RyR}_{2}\right)$ and large-conductance $\mathrm{Ca}^{2+}$-activated $\mathrm{K}^{+}\left(\mathrm{BK}_{\mathrm{Ca}}\right)$ channel activity and subsequently enhances $\mathrm{Ca}^{2+}$ spark/STOC coupling, leading to reduced uterine arterial myogenic tone. $\mathrm{E}_{2} \beta$ also increases production/release of nitric oxide (NO), hydrogen sulfide $\left(\mathrm{H}_{2} \mathrm{~S}\right)$ and prostacyclin $\left(\mathrm{PGI}_{2}\right)$ via upregulating the expression of NOS3, CBS and COX1 in uterine arteries. These vasodilators, through receptor or nonreceptor mechanisms to activate protein kinase A (PKA) and protein kinase $\mathrm{G}$ (PKG), promote vasodilation and blunt vasoconstriction, resulting in an overall decrease in uterine vascular tone.

\section{2. $\mathrm{Ca}^{2+}$ Spark/STOC Coupling}

Myogenic tone in resistance arteries/arterioles is regulated by both global and local $\mathrm{Ca}^{2+}$ in vascular smooth muscle cells [38]. An increase in intraluminal pressure results in membrane depolarization and opening of the L-type $\mathrm{Ca}^{2+}$ channel Cav1.2. The subsequent increase in global $\mathrm{Ca}^{2+}$ concentration due to $\mathrm{Ca}^{2+}$ influx activates contractile proteins in vascular smooth muscle and increases contractions. On the other hand, increased intraluminal pressure also leads to localized and concentrated $\mathrm{Ca}^{2+}$ release events $\left(\mathrm{Ca}^{2+}\right.$ sparks $)$ mediated by ryanodine receptors (RyRs) in the sarcoplasmic reticulum of vascular smooth muscle cells. $\mathrm{Ca}^{2+}$ sparks in turn activate adjacent $\mathrm{BK}_{\mathrm{Ca}}$ channels in the plasma membrane, producing spontaneous transient outward currents (STOCs). The $\beta 1$ subunit of the $\mathrm{BK}_{\mathrm{Ca}}$ channel functions as the sensor of $\mathrm{Ca}^{2+}$ sparks and transmits the $\mathrm{Ca}^{2+}$ signal to the $\mathrm{BK}_{\mathrm{Ca}}$ channel [204]. $\mathrm{K}^{+}$efflux carried by STOCs causes membrane hyperpolarization and closure of $\mathrm{Ca}_{\mathrm{V}} 1.2$, resulting in vasorelaxation. Thus, the $\mathrm{Ca}^{2+}$ spark/STOC coupling is an important mechanism to regulate myogenic tone and blood flow $[205,206]$. Preg- 
nancy has been shown to lower ovine uterine arterial myogenic tone by promoting $\mathrm{Ca}^{2+}$ spark/STOC coupling $[207,208]$. This is achieved by estrogen-mediated upregulation of the expression/activity of $\mathrm{BK}_{\mathrm{Ca}}$ channel $\beta 1$ subunit and RyR2 [42,207,209,210] (Figure 2). As expected, basal uterine blood flow in nonpregnant sheep is negligibly affected by $\mathrm{BK}_{\mathrm{Ca}}$ channel inhibitor tetraethylammonium [102]. However, basal uterine blood flow in pregnant sheep and estrogen-induced increase in uterine blood flow in both nonpregnant and pregnant ewes are dramatically reduced by the $\mathrm{BK}_{\mathrm{Ca}}$ channel blockade $[102,211,212]$. Furthermore, pregnancy-induced decrease in uterine vascular resistance is absent in mice with genetically deleted $\mathrm{BK}_{\mathrm{Ca}}$ channel $\alpha$ subunit [213].

Both $\mathrm{BK}_{\mathrm{Ca}}$ channel $\alpha$ and $\beta 1$ subunits are expressed in human and ovine uterine arteries $[42,102,214]$. Only the $\beta 1$ subunit, but not the $\alpha$ subunit, in uterine artery is upregulated in ovine pregnancy $[42,210]$. The expression of the $\gamma 1$ subunit is similarly increased in mouse uterine artery [213]. The $\gamma 1$ subunit also increases $\mathrm{BK}_{\mathrm{Ca}}$ channel activation and promotes vasodilation of uterine arteries. Notably, the $\mathrm{BK}_{\mathrm{Ca}}$ channel mediates uterine vasodilation induced by $\mathrm{NO}, \mathrm{H}_{2} \mathrm{~S}$, calcitonin gene-related peptide and adrenomedullin $[55,56,210,214,215]$. However, the vasodilation of human placenta vessels induced by $\mathrm{H}_{2} \mathrm{~S}$ is mediated by $\mathrm{NO}$ and ATP-sensitive $\mathrm{K}^{+}\left(\mathrm{K}_{\mathrm{ATP}}\right)$ channels [133]. Interestingly, the $\mathrm{BK}_{\mathrm{Ca}}$ channel can be activated by $\mathrm{E}_{2} \beta$ through directly binding to the $\beta 1$ subunit $[216,217]$. Hence, the increased uterine blood flow in response to $E_{2} \beta$ probably in part is mediated by directly activating the $\mathrm{BK}_{\mathrm{Ca}}$ channel in uterine arteries. The $\mathrm{BK}_{\mathrm{Ca}}$ channel also contributes to the refractoriness to vasoconstrictors in uterine arteries in pregnancy. Phenylephrine-induced contraction of ovine uterine arteries is potentiated by the $\mathrm{BK}_{\mathrm{Ca}}$ channel inhibitor tetraethylammonium [210]. Similarly, phenylephrine infusion-induced increase in uterine vascular resistance in pregnant sheep is enhanced by tetraethylammonium [218]. Pregnancy increases $\mathrm{AT}_{2}$ receptor expression in the endothelium of uterine arteries in pregnant rats, which is associated with blunted uterine vasoconstriction to angiotensin II [202]. As $\mathrm{BK}_{\mathrm{Ca}}$ channel activity is enhanced by activating $\mathrm{AT}_{2}$ receptor [219], the refractoriness of uterine arteries to angiotensin II in pregnancy is probably mediated by $\mathrm{AT}_{2}$ receptor-stimulated $\mathrm{BK}_{\mathrm{Ca}}$ channel activity. Moreover, PKCmediated vasoconstriction of ovine uterine arteries is enhanced by inhibiting the $\mathrm{BK}_{\mathrm{Ca}}$ channel with tetraethylammonium [220]. Overall, the activation of the $\mathrm{BK}_{\mathrm{Ca}}$ channel functions as a negative feedback mechanism to limit excessive vasoconstriction. However, the $\beta 1$ subunit is downregulated in human placental chorionic plate arteries and in $\mathrm{HU}-$ VECs from preeclamptic patients [116,221]. High-altitude pregnancy also suppresses $\beta 1$ subunit expression in ovine uterine arteries [48]. The downregulation of the $\beta 1$ subunit in preeclampsia could contribute to the increased uteroplacental vascular resistance and reduced uteroplacental blood flow.

The expression of $\mathrm{BK}_{\mathrm{Ca}}$ channel $\beta 1$ subunit-encoding gene $\mathrm{KCNMB1}$ in ovine uterine arteries is determined by the dynamics of DNA methylation and demethylation. In uterine arteries of nonpregnant sheep, the Sp1-binding site $\left(\mathrm{Sp} 1^{-380}\right)$ at the KCNMB1 promoter is hypermethylated, which blocks transcription factor binding and inhibits KCNMB1 expression [222]. The $C p G$ methylation at $S p 1^{-380}$ is reduced in pregnancy owing to $E_{2} \beta-E R$ signaling-mediated upregulation of TET1 expression/activity [184]. The demethylation allows ER $\alpha$ and Sp1 co-binding, leading to enhanced KCNMB1 expression and hence channel activity. However, $\mathrm{Ca}^{2+}$ spark/STOC coupling in uterine arteries is suppressed in high-altitude pregnancy due to hypoxia-mediated suppression of $\mathrm{E}_{2} \beta$-induced upregulation of KCNMB1 and RYR and the direct effect of hypoxia on both genes via increased DNA methylation and/or miR-210-mediated degradation of KCNMB1 and RYR2 [48,222,223].

\subsection{HIFs, Oxidative Stress and Endoplasmic Reticulum Stress}

Uteroplacental tissues exhibit a hypoxic phenotype in preeclampsia as evidenced by the similarity in global gene expression in placentas from preeclamptic patients and high-altitude pregnancy and in placentas exposed to hypoxia in vitro [224]. Expression of hypoxia inducible factors (HIFs) is increased in preeclamptic placentas and in uter- 
ine arteries from high-altitude pregnant sheep $[225,226]$. DNMT3b contains a HIF- $1 \alpha$ binding site in its promoter [227]. The upregulation of DNMT3b in uterine arteries of high-altitude pregnant sheep is probably mediated by HIF-1, leading to hypermethylation of ESR1 and KCNMB1 and suppressed expression [181,187]. In addition, miR-210 is a direct target of HIFs and is upregulated in both preeclamptic placenta and ovine uterine arteries from high-altitude pregnancy $[188,228,229]$. High-altitude pregnancy also induces oxidative stress and endoplasmic reticulum stress in human placentas and ovine uterine arteries [223,230-232]. Likewise, chronic hypoxia induces endoplasmic reticulum stress in rat placentas [233]. These altercations probably work concertedly, leading to the downregulation of $\mathrm{BK}_{\mathrm{Ca}}$ channel $\beta 1$ subunit and RyR2 expression/activity and the subsequent increase in uteroplacental vascular tone. For example, hypoxia through HIF-1 triggers ESR1 and KCNMB1 promoter hypermethylation by inducing DNMT expression and by reducing TET1 expression via miR-210-mediated mRNA degradation/translation inhibition [181,188,189], thus suppressing ESR1 and KCNMB1 expression in ovine uterine arteries in high-altitude pregnancy. In addition, miR-210 also directly targets KCNMB1 and RYR2, causing their degradation [234]. Moreover, ROS could directly suppress $\mathrm{BK}_{\mathrm{Ca}}$ channel activity in ovine uterine arteries from high-altitude pregnancy [226,232]. Furthermore, endoplasmic reticulum stress has been shown to decrease the protein abundance of $\mathrm{BK}_{\mathrm{Ca}}$ channel $\beta 1$ subunit by promoting ubiquitin ligase-mediated degradation of the $\beta 1$ subunit in vascular smooth muscle cells [235]. Intriguingly, whereas both oxidative stress and endoplasmic reticulum stress suppress $\mathrm{Ca}^{2+}$ spark/STOC coupling, only oxidative stress disrupts estrogen-mediated regulation of STOCs in ovine uterine arteries from high-altitude pregnancy [234].

\subsection{Kinase Signaling}

Protein kinases are important regulators of vascular contractility through phosphorylation of target proteins [236,237]. In general, activation of PKG induces vasorelaxation, whereas activation of protein kinase C (PKC) promotes vasoconstriction. Uterine vascular function is also subject to modulation by protein kinases.

It is well established that $\mathrm{NO}$ induces vasorelaxation by stimulating soluble guanylyl cyclases to generate cGMP, which in turn activates PKG [238]. Activation of PKG has been shown to augment $\mathrm{Ca}^{2+}$ spark/STOC coupling by increasing $\mathrm{Ca}^{2+}$ sparks and/or increased $\mathrm{BK}_{\mathrm{Ca}}$ channel activity through phosphorylation, resulting in reduced myogenic tone [239-242]. $\mathrm{BK}_{\mathrm{Ca}}$ channel activity is stimulated by PKG in uterine arterial vascular smooth muscle cells [102]. Along with increased eNOS expression and NO production, cGMP, PKG and $\mathrm{BK}_{\mathrm{Ca}}$ channel activity are all increased in the uterine arteries of pregnant sheep [210]. Expectedly, the NO donor sodium nitroprusside increases STOCs in uterine arterial vascular smooth muscle cells from pregnant sheep (unpublished data). In addition, activation of PKG also blunts uterine vasoconstriction [243]. The expression of PKG is reduced in decidua form preeclamptic patients [244]. The downregulation of PKG is probably induced by chronic hypoxia [245]. High-altitude pregnancy also impairs PKGmediated modulation of the $\mathrm{BK}_{\mathrm{Ca}}$ channel by reducing the association of $\mathrm{PKG}$ with $\mathrm{BK}_{\mathrm{Ca}}$ channels in vascular smooth muscle cells of ovine cerebral arteries [246].

$\mathrm{PKC}$ is an important mediator of vasoconstriction induced by various vasoconstrictors $[237,247]$. PKC contributes to vascular contractility through regulating ion channels and ultimately $\left[\mathrm{Ca}^{2+}\right]_{i}$, increasing $\mathrm{Ca}^{2+}$ sensitivity of the contractile proteins and activating $\mathrm{Ca}^{2+}$-independent contraction [237]. In guinea pig uterine arteries, PKC is a major contributor to vasocontraction induced by norepinephrine [248] and probably to endothelin-1 and angiotensin II, as seen in the other vascular beds [247]. Activation of PKC has been shown to inhibit $\mathrm{Ca}^{2+}$ spark frequency in cerebral arteries [249] and to suppress $\mathrm{BK}_{\mathrm{Ca}}$ channel activity in uterine arteries [42]. PKC activity and its signal pathway in ovine and rat uterine arteries and other vessels are reduced in pregnancy, apparently due to $E_{2} \beta^{\prime}$ s action [41,250-253]. As expected, the downregulation of PKC activity contributes to reduced uterine arterial myogenic tone in ovine pregnancy [41]. However, the $E_{2} \beta$-mediated 
downregulation of PKC activity in ovine uterine arteries is diminished in high-altitude pregnancy owing to hypoxia-induced suppression of $E_{2} \beta$-ER signaling, resulting in increased PKC activity $[180,254]$. Similarly, HUVECs exposed to serum from preeclamptic patients display elevated PKC activity [255]. The elevated PKC activity in turn inhibits $\mathrm{BK}_{\mathrm{Ca}}$ activity [220]. Consequently, vasoconstriction to PKC activation and myogenic tone in uterine arteries are increased in uterine arteries from high-altitude pregnancy $[180,256]$.

\subsection{Angiogenic Balance}

Vascular endothelial growth factor (VEGF) and placental growth factor (PlGF), members of the VEGF family, are predominantly expressed in the placenta. Their expression in the placenta increases as pregnancy progresses [257]. Both of them play a vital role in angiogenesis $[258,259]$. In addition, they are also potent vasodilators and participate in regulating uterine vascular tone $[257,260,261]$. Local overexpression of VEGF increases uterine blood flow in pregnant sheep and reduces uterine vasoconstriction to phenylephrine, which is accompanied by increased levels of phosphorylated eNOS ${ }^{S e r 1177}$ [262-264]. Similarly, VEGF also increases phosphorylation of eNOS ${ }^{S e r 1777}$ in HUVECs [265]. These observations suggest that VEGF initiates vasodilation via stimulating NO release. Indeed, the vasodilation of rat uterine arteries induced by VEGF and PlGF is primarily mediated by NO $[257,261]$. Pregnancy through the $E_{2} \beta$-ER signaling pathway enhances VEGF-induced vasodilation of rat uterine arteries $[257,266]$. VEFG-stimulated eNOS activity and production of NO and $\mathrm{H}_{2} \mathrm{~S}$ are enhanced in human and ovine pregnancy [267-269]. A $24 \mathrm{~h}$ incubation of human uterine arteries with PIGF also blunts angiotensin II-induced vasoconstriction [270]. sFlt-1 also belongs to the VEGF family and is a splice variant of the VEGF receptor Flt1 lacking the cytoplasmic and transmembrane domains. In preeclamptic patients, levels of sFlt-1 in both the placenta and blood are increased [271-275]. The increased expression of sFlt-1 in the preeclamptic placenta is mediated by HIFs [276-278]. sFlt-1 functions as a scavenger of VEGF and PIGF and reduces the bioavailability of VEGF and PlGF [279,280], despite that circulating VEGF is increased owing to hypoxia in preeclampsia [281-283]. As expected, the circulating level of PlGF is reduced in preeclampsia [271,274]. Elevated sFlt-1 in the circulation leads to endothelial dysfunction [280]. Not surprisingly, exposure of bovine aortic endothelial cells to sFlt- 1 and serum from preeclamptic patients inhibits mitochondrial respiration and increases mitochondrial ROS production [284]. In addition, VEGF-stimulated phosphorylation of eNOS ${ }^{\text {Ser1177 }}$ in HUVECs is reduced by sFlt-1 [265]. Moreover, prolonged treatment of human uterine arteries with sFlt-1 enhances vasoconstriction to angiotensin II [270]. The role of sFlt-1 in the pathogenesis of preeclampsia is corroborated by the finding that chronic infusion of sFlt- 1 into pregnant rats produces a preeclampsia phenotype [285].

\subsection{Inflammation}

Tumor necrosis factor $\alpha(\mathrm{TNF} \alpha)$ is a potent mediator of inflammatory and immune functions. In preeclampsia, the production/release of TNF $\alpha$ in the placenta is increased [286-288]. Correspondingly, circulating TNF $\alpha$ level increases in women with preeclampsia [289-292]. Hypoxia or hypoxia/reoxygenation is found to stimulate TNF $\alpha$ production in human placental villous explants $[293,294]$. Uteroplacental vascular function is impaired by the increased circulating TNF $\alpha$. TNF $\alpha$ promotes mitochondrial ROS production and eNOS downregulation in HUVECs [295-297]. Pregnancy enhances sustained $\mathrm{Ca}^{2+}$ bursts and eNOS activity in ovine uterine artery endothelial cells by promoting connexin 43 function, which is suppressed by TNF $\alpha[298,299]$. Further evidence supporting the involvement of TNF $\alpha$ in uterine vascular dysfunction in preeclampsia comes from animal studies. Chronic administration of TNF $\alpha$ promotes preeclamptic symptoms such as hypertension and proteinuria in pregnant baboons and rats [300,301]. Pregnant mice exposed to chronic intermittent hypoxia display uterine vascular dysfunction as evidenced by reduced endothelium-dependent vasodilatation and enhanced vasoconstriction, which are associated with increased plasma TNF $\alpha$ and sFlt-1 [302]. In two rat models of preeclamp- 
sia, administration of the TNF $\alpha$ inhibitor etanercept restores uterine vascular function by increasing endothelium-dependent vasorelaxation to acetylcholine and decreasing vasoconstriction to norepinephrine in uterine arteries of RUPP rats and stroke-prone spontaneously hypertensive rats, resulting in reduced uterine vascular resistance [303,304].

\subsection{Autoimmunity}

Angiotensin II type 1-receptor autoantibody $\left(\mathrm{AT}_{1}-\mathrm{AA}\right)$ is an agonistic autoantibody to the $\mathrm{AT}_{1}$ receptor. $\mathrm{AT}_{1}-\mathrm{AA}$ induces vasoconstriction via activating $\mathrm{AT}_{1}$ receptor [305]. Preeclamptic patients also display elevated $\mathrm{AT}_{1}-\mathrm{AA}$ in the circulation [274,305-307]. The detection of $\mathrm{AT}_{1}-\mathrm{AA}$ in serum is associated with abnormal uteroplacental perfusion [308]. Chronic infusion of $\mathrm{AT}_{1}-\mathrm{AA}$ in pregnant rats increases uterine vascular resistance [309]. Notably, the elevated uterine vascular resistance is decreased by 'n7AAc', a capped inhibitory peptide binding to the $\mathrm{AT}_{1}$ - $\mathrm{AA}$ and blocking $\mathrm{AT}_{1}$-AAs from binding to the $\mathrm{AT}_{1}$ receptor [310]. Prolonged incubation of HUVECs with serum from preeclamptic patients suppresses mitochondrial respiration and increases mitochondrial ROS [311]. The increased mitochondrial ROS following exposure to serum from preeclamptic patients is reduced by ' $n 7 A A C^{\prime}$ [311]. Similarly, the mitochondrial ROS in HUVECs induced by serum of RUPP rats is also lowered by ' $n 7 A A C^{\prime}$ [312]. $\mathrm{AT}_{1}$-AA inhibition in RUPP rats by administration of ' $n 7 A A c$ ' reduces mitochondrial ROS in the placenta and ablates preeclamptic symptoms [310,312]. In a preeclampsia model induced by immunizing pregnant BALB/c mice with $\mathrm{AT}_{1}-\mathrm{AA}$, the expression of the $\mathrm{BK}_{\mathrm{Ca}}$ channel $\beta 1$ subunit is reduced in mesenteric arteries [313].

\section{Conclusions}

Uteroplacental vessels undergo adaptation to accommodate increased uteroplacental blood flow in pregnancy. Observations from human and animal studies suggest that this adaptation involves functional alterations in both vascular smooth muscle cells and endothelial cells. $\mathrm{E}_{2} \beta$ appears to be the primary mediator of the functional adaptation in pregnancy, increasing the $\mathrm{Ca}^{2+}$ spark/STOC coupling, eNOS expression/activity and cGMP-PKG signaling pathway, to name a few. These changes ultimately lead to reduced uterine vascular resistance. However, the functional adaptation of uterine arteries is impaired by the aberrant $\mathrm{E}_{2} \beta$ production and its associated signaling pathways and by bioactive factors produced in preeclampsia. Extensive research, including clinical and experimental studies, has enriched our understanding of the functional changes of uteroplacental vasculature in physiological and pathophysiological conditions of pregnancy. However, our knowledge is still incomplete, which requires us to explore further. It also remains challenging to translate laboratory discoveries into patient care for preeclampsia, and more efforts are needed to close the gap between the bench and the bedside.

Author Contributions: Conceptualization and writing, X.H. and L.Z. All authors have read and agreed to the published version of the manuscript.

Funding: This work was funded by National Institutes of Health Grants HD083132 (L.Z.), HL128209 (L.Z.), HL137649 (L.Z.) and HL149608 (L.Z.).

Conflicts of Interest: The authors declare no conflict of interest.

\section{References}

1. Monk, C.; Lugo-Candelas, C.; Trumpff, C. Prenatal Developmental Origins of Future Psychopathology: Mechanisms and Pathways. Annu. Rev. Clin. Psychol. 2019, 15, 317-344. [CrossRef]

2. Osol, G.; Mandala, M. Maternal Uterine Vascular Remodeling During Pregnancy. Physiology 2009, 24, 58-71. [CrossRef]

3. Hunter, S.; Robson, S.C. Adaptation of the maternal heart in pregnancy. Br. Heart J. 1992, 68, 540-543. [CrossRef]

4. Mahendru, A.A.; Everett, T.R.; Wilkinson, I.B.; Lees, C.C.; McEniery, C.M. A longitudinal study of maternal cardiovascular function from preconception to the postpartum period. J. Hypertens. 2014, 32, 849-856. [CrossRef] [PubMed]

5. Sanghavi, M.; Rutherford, J.D. Cardiovascular Physiology of Pregnancy. Circulation 2014, 130, 1003-1008. [CrossRef] [PubMed]

6. Jauniaux, E.; Watson, A.L.; Hempstock, J.; Bao, Y.-P.; Skepper, J.N.; Burton, G.J. Onset of Maternal Arterial Blood Flow and Placental Oxidative Stress: A Possible Factor in Human Early Pregnancy Failure. Am. J. Pathol. 2000, 157, 2111-2122. [CrossRef] 
7. Saghian, R.; Bogle, G.; James, J.L.; Clark, A.R. Establishment of maternal blood supply to the placenta: Insights into plugging, unplugging and trophoblast behaviour from an agent-based model. Interface Focus 2019, 9, 20190019. [CrossRef]

8. Lang, U.; Baker, R.; Braems, G.; Zygmunt, M.; Künzel, W.; Clark, K. Uterine blood flow-A determinant of fetal growth. Eur. J. Obstet. Gynecol. Reprod. Biol. 2003, 110, S55-S61. [CrossRef]

9. Huppertz, B. Placental origins of preeclampsia: Challenging the current hypothesis. Hypertension 2008, 51, 970-975. [CrossRef]

10. Redman, C.W.; Sargent, I.L. Latest advances in understanding preeclampsia. Science 2005, 308, 1592-1594. [CrossRef]

11. Gilbert, J.S.; Ryan, M.J.; Lamarca, B.B.; Sedeek, M.; Murphy, S.R.; Granger, J.P. Pathophysiology of hypertension during preeclampsia: Linking placental ischemia with endothelial dysfunction. Am. J. Physiol. Heart Circ. Physiol. 2008, 294, H541-H550. [CrossRef]

12. Rana, S.; Lemoine, E.; Granger, J.P.; Karumanchi, S.A. Preeclampsia: Pathophysiology, Challenges, and Perspectives. Circ. Res. 2019, 124, 1094-1112. [CrossRef]

13. Brown, M.A.; Magee, L.A.; Kenny, L.C.; Karumanchi, S.A.; McCarthy, F.P.; Saito, S.; Hall, D.R.; Warren, C.E.; Adoyi, G.; Ishaku, S.; et al. Hypertensive Disorders of Pregnancy: ISSHP Classification, Diagnosis, and Management Recommendations for International Practice. Hypertension 2018, 72, 24-43. [CrossRef] [PubMed]

14. Poon, L.C.; Shennan, A.; Hyett, J.A.; Kapur, A.; Hadar, E.; Divakar, H.; McAuliffe, F.; Costa, F.D.S.; von Dadelszen, P.; McIntyre, H.D.; et al. The International Federation of Gynecology and Obstetrics (FIGO) initiative on pre-eclampsia: A pragmatic guide for first-trimester screening and prevention. Int. J. Gynecol. Obstet. 2019, 145, 1-33. [CrossRef]

15. American College of Obstetricians and Gynecologists. Gestational Hypertension and Preeclampsia: ACOG Practice Bulletin, Number 222. Obs. Gynecol 2020, 135, e237-e260. [CrossRef]

16. Tooher, J.; Thornton, C.; Makris, A.; Ogle, R.; Korda, A.; Hennessy, A. All Hypertensive Disorders of Pregnancy Increase the Risk of Future Cardiovascular Disease. Hypertension 2017, 70, 798-803. [CrossRef]

17. Andraweera, P.H.; Gatford, K.L.; Care, A.S.; Bianco-Miotto, T.; Lassi, Z.S.; Dekker, G.A.; Arstall, M.; Roberts, C. Mechanisms linking exposure to preeclampsia in utero and the risk for cardiovascular disease. J. Dev. Orig. Health Dis. 2020, 11, 235-242. [CrossRef]

18. Turbeville, H.R.; Sasser, J.M. Preeclampsia beyond Pregnancy: Long-Term Consequences for Mother and Child. Am. J. Physiol. Physiol. 2020, 318, F1315-F1326. [CrossRef]

19. Melchiorre, K.; Thilaganathan, B.; Giorgione, V.; Ridder, A.; Memmo, A.; Khalil, A. Hypertensive Disorders of Pregnancy and Future Cardiovascular Health. Front. Cardiovasc. Med. 2020, 7, 59. [CrossRef] [PubMed]

20. Degner, K.; Magness, R.R.; Shah, D.M. Establishment of the Human Uteroplacental Circulation: A Historical Perspective. Reprod. Sci. 2017, 24, 753-761. [CrossRef] [PubMed]

21. Enriquez, P.J.V.; McKerracher, L.J.; Elliot, M.G. Pre-Eclampsia and Maternal-Fetal Conflict. Evol. Med. Public Health 2018, 2018, 217-218. [CrossRef]

22. Gatford, K.L.; Andraweera, P.H.; Roberts, C.T.; Care, A.S. Animal Models of Preeclampsia: Causes, Consequences, and Interventions. Hypertension 2020, 75, 1363-1381. [CrossRef]

23. Campbell, S.; Diaz-Recasens, J.; Griffin, D.R.; Cohen-Overbeek, T.E.; Pearce, J.M.; Willson, K.; Teague, M.J. New doppler technique for assessing uteroplacental blood flow. Lancet 1983, 1, 675-677. [CrossRef]

24. Konje, J.C.; Kaufmann, P.; Bell, S.C.; Taylor, D.J. A longitudinal study of quantitative uterine blood flow with the use of color power angiography in appropriate for gestational age pregnancies. Am. J. Obstet. Gynecol. 2001, 185, 608-613. [CrossRef]

25. Palmer, S.K.; Zamudio, S.; Coffin, C.; Parker, S.; Stamm, E.; Moore, L. Quantitative estimation of human uterine artery blood flow and pelvic blood flow redistribution in pregnancy. Obstet. Gynecol. 1992, 80, 1000-1006.

26. Flo, K.; Wilsgaard, T.; Acharya, G. A New Non-Invasive Method for Measuring Uterine Vascular Resistance and Its Relationship to Uterine Artery Doppler Indices: A Longitudinal Study. Ultrasound Obstet. Gynecol 2011, 37, 538-542. [CrossRef] [PubMed]

27. Rosenfeld, C.R.; Morriss, F.H., Jr.; Makowski, E.L.; Meschia, G.; Battaglia, F.C. Circulatory changes in the reproductive tissues of ewes during pregnancy. Gynecol. Obstet. Investig. 1974, 5, 252-268. [CrossRef] [PubMed]

28. Peeters, L.L.H.; Sparks, J.W.; Grutters, G.; Girard, J.; Battaglia, F.C. Uteroplacental Blood Flow during Pregnancy in Chronically Catheterized Guinea Pigs. Pediatr. Res. 1982, 16, 716-720. [CrossRef]

29. Dowell, R.T.; Kauer, C.D. Maternal hemodynamics and uteroplacental blood flow throughout gestation in conscious rats. Methods Find. Exp. Clin. Pharmacol. 1997, 19, 613-625. [PubMed]

30. Leiberman, J.R.; Meizner, I.; Mazor, M.; Insler, V. Blood supply to the uterus in preeclampsia. Eur. J. Obstet. Gynecol. Reprod. Biol. 1988, 28, 23-27. [CrossRef]

31. Lunell, N.O.; Nylund, L.E.; Lewander, R.; Sarby, B.; Thornström, S. Uteroplacental Blood Flow in Pre-Eclampsia Measurements with Indium-113M and a Computer-Linked Gamma Camera. Clin. Exp. Hypertens. Part B Hypertens. Pregnancy 1982, 1, 105-117. [CrossRef]

32. Takata, M.; Nakatsuka, M.; Kudo, T. Differential Blood Flow in Uterine, Ophthalmic, and Brachial Arteries of Preeclamptic Women. Obstet. Gynecol. 2002, 100, 931-939. [CrossRef]

33. Palmer, S.K.; Moore, L.G.; Young, D.A.; Cregger, B.; Berman, J.C.; Zamudio, S. Altered blood pressure course during normal pregnancy and increased preeclampsia at high altitude (3100 meters) in Colorado. Am. J. Obstet. Gynecol. 1999, 180, 1161-1168. [CrossRef]

34. Zamudio, S. High-Altitude Hypoxia and Preeclampsia. Front. Biosci. 2007, 12, 2967-2977. [CrossRef] [PubMed] 
35. Zamudio, S.; Palmer, S.K.; Droma, T.; Stamm, E.; Coffin, C.; Moore, L.G. Effect of altitude on uterine artery blood flow during normal pregnancy. J. Appl. Physiol. 1995, 79, 7-14. [CrossRef]

36. Tykocki, N.R.; Boerman, E.M.; Jackson, W.F. Smooth Muscle Ion Channels and Regulation of Vascular Tone in Resistance Arteries and Arterioles. Compr. Physiol. 2017, 7, 485-581. [CrossRef]

37. Davis, M.J.; Hill, M. Signaling Mechanisms Underlying the Vascular Myogenic Response. Physiol. Rev. 1999, 79, $387-423$. [CrossRef]

38. Hill, M.A.; Yang, Y.; Ella, S.R.; Davis, M.J.; Braun, A.P. Large conductance, $\mathrm{Ca}^{2+}$-activated $\mathrm{K}^{+}$channels (BKCa) and arteriolar myogenic signaling. FEBS Lett. 2010, 584, 2033-2042. [CrossRef]

39. Veerareddy, S.; Cooke, C.-L.M.; Baker, P.N.; Davidge, S.T. Vascular adaptations to pregnancy in mice: Effects on myogenic tone. Am. J. Physiol. Heart Circ. Physiol. 2002, 283, H2226-H2233. [CrossRef]

40. Marshall, S.A.; Senadheera, S.N.; Jelinic, M.; O'Sullivan, K.; Parry, L.J.; Tare, M. Relaxin Deficiency Leads to Uterine Artery Dysfunction During Pregnancy in Mice. Front. Physiol. 2018, 9, 255. [CrossRef]

41. Xiao, D.; Buchholz, J.N.; Zhang, L. Pregnancy attenuates uterine artery pressure-dependent vascular tone: Role of PKC/ERK pathway. Am. J. Physiol. Heart Circ. Physiol. 2006, 290, H2337-H2343. [CrossRef]

42. Hu, X.-Q.; Xiao, D.; Zhu, R.; Huang, X.; Yang, S.; Wilson, S.; Zhang, L. Pregnancy Upregulates Large-Conductance Ca ${ }^{2+}$-Activated $\mathrm{K}^{+}$Channel Activity and Attenuates Myogenic Tone in Uterine Arteries. Hypertension 2011, 58, 1132-1139. [CrossRef] [PubMed]

43. Osol, G.; Cipolla, M. Interaction of myogenic and adrenergic mechanisms in isolated, pressurized uterine radial arteries from late-pregnant and nonpregnant rats. Am. J. Obstet. Gynecol. 1993, 168, 697-705. [CrossRef]

44. Eckman, D.M.; Gupta, R.; Rosenfeld, C.R.; Morgan, T.M.; Charles, S.M.; Mertz, H.; Moore, L.G. Pregnancy increases myometrial artery myogenic tone via NOS- or COX-independent mechanisms. Am. J. Physiol. Integr. Comp. Physiol. 2012, 303, R368-R375. [CrossRef] [PubMed]

45. Kublickiene, K.R.; Lindblom, B.; Kruger, K.; Nisell, H. Preeclampsia: Evidence for impaired shear stress-mediated nitric oxide release in uterine circulation. Am. J. Obstet. Gynecol. 2000, 183, 160-166. [CrossRef]

46. Reho, J.J.; Toot, J.D.; Peck, J.; Novak, J.; Yun, Y.H.; Ramirez, R.J. Increased Myogenic Reactivity of Uterine Arteries from Pregnant Rats with Reduced Uterine Perfusion Pressure. Pregnancy Hypertens. 2012, 2, 106-114. [CrossRef] [PubMed]

47. Chang, K.; Xiao, D.; Huang, X.; Longo, L.D.; Zhang, L. Chronic hypoxia increases pressure-dependent myogenic tone of the uterine artery in pregnant sheep: Role of ERK/PKC pathway. Am. J. Physiol. Heart Circ. Physiol. 2009, 296, H1840-H1849. [CrossRef]

48. Hu, X.-Q.; Xiao, D.; Zhu, R.; Huang, X.; Yang, S.; Wilson, S.; Zhang, L. Chronic Hypoxia Suppresses Pregnancy-Induced Upregulation of Large-Conductance $\mathrm{Ca}^{2+}$-Activated $\mathrm{K}^{+}$Channel Activity in Uterine Arteries. Hypertension 2012, 60, $214-222$. [CrossRef]

49. Vanhoutte, P.M. Endothelium and Control of Vascular Function. State of the Art lecture. Hypertension 1989, 13, 658-667. [CrossRef]

50. Ni, Y.; Meyer, M.; Osol, G. Gestation increases nitric oxide-mediated vasodilation in rat uterine arteries. Am. J. Obstet. Gynecol. 1997, 176, 856-864. [CrossRef]

51. Nelson, S.H.; Steinsland, O.S.; Suresh, M.S.; Lee, N.M. Pregnancy augments nitric oxide-dependent dilator response to acetylcholine in the human uterine artery. Hum. Reprod. 1998, 13, 1361-1367. [CrossRef]

52. White, M.M.; McCullough, R.E.; Dyckes, R.; Robertson, A.D.; Moore, L.G. Chronic hypoxia, pregnancy, and endotheliummediated relaxation in guinea pig uterine and thoracic arteries. Am. J. Physiol. Heart Circ. Physiol. 2000, 278, H2069-H2075. [CrossRef]

53. Thompson, L.P.; Weiner, C.P. Pregnancy enhances G protein activation and nitric oxide release from uterine arteries. Am. J. Physiol. Heart Circ. Physiol. 2001, 280, H2069-H2075. [CrossRef] [PubMed]

54. Cooke, C.-L.M.; Davidge, S.T. Pregnancy-Induced Alterations of Vascular Function in Mouse Mesenteric and Uterine Arteries1. Biol. Reprod. 2003, 68, 1072-1077. [CrossRef]

55. Gangula, P.R.; Thota, C.; Wimalawansa, S.J.; Bukoski, R.D.; Yallampalli, C. Mechanisms Involved in Calcitonin Gene-Related Peptide-Induced Relaxation in Pregnant Rat Uterine Artery. Biol. Reprod. 2003, 69, 1635-1641. [CrossRef]

56. Ross, G.R.; Yallampalli, U.; Gangula, P.R.; Reed, L.; Sathishkumar, K.; Gao, H.; Chauhan, M.; Yallampalli, C. Adrenomedullin relaxes rat uterine artery: Mechanisms and influence of pregnancy and estradiol. Endocrinology 2010, 151, 4485-4493. [CrossRef] [PubMed]

57. Weiner, C.P.; Thompson, L.P.; Liu, K.Z.; Herrig, J.E. Pregnancy reduces serotonin-induced contraction of guinea pig uterine and carotid arteries. Am. J. Physiol. Heart Circ. Physiol. 1992, 263, H1764-H1769. [CrossRef]

58. Weiner, C.; Liu, K.Z.; Thompson, L.; Herrig, J.; Chestnut, D. Effect of pregnancy on endothelium and smooth muscle: Their role in reduced adrenergic sensitivity. Am. J. Physiol. Heart Circ. Physiol. 1991, 261, H1275-H1283. [CrossRef] [PubMed]

59. Weiner, C.P.; Martinez, E.; Chestnut, D.H.; Ghodsi, A. Effect of pregnancy on uterine and carotid artery response to norepinephrine, epinephrine, and phenylephrine in vessels with documented functional endothelium. Am. J. Obstet. Gynecol. 1989, 161, 1605-1610. [CrossRef]

60. Magness, R.R.; Rosenfeld, C.R. Systemic and uterine responses to $\alpha$-adrenergic stimulation in pregnant and nonpregnant ewes. Am. J. Obstet. Gynecol. 1986, 155, 897-904. [CrossRef]

61. Jovanovic, S.; Grbovic, L.; Jovanovic, A. Pregnancy is associated with altered response to neuropeptide Y in uterine artery. Mol. Hum. Reprod. 2000, 6, 352-360. [CrossRef] 
62. McElvy, S.; Greenberg, S.G.; Mershon, J.L.; Yang, D.S.; Magill, C.; Clark, K.E. Mechanism of uterine vascular refractoriness to endothelin-1 in pregnant sheep. Am. J. Physiol. Heart Circ. Physiol. 2001, 281, H804-H812. [CrossRef] [PubMed]

63. Yang, D.; Clark, K.E. Effect of endothelin-1 on the uterine vasculature of the pregnant and estrogen-treated nonpregnant sheep. Am. J. Obstet. Gynecol. 1992, 167, 1642-1650. [CrossRef]

64. McCarthy, A.L.; Woolfson, R.G.; Raju, S.K.; Poston, L. Abnormal endothelial cell function of resistance arteries from women with preeclampsia. Am. J. Obstet. Gynecol. 1993, 168, 1323-1330. [CrossRef]

65. Knock, G.A.; Poston, L. Bradykinin-Mediated relaxation of isolated maternal resistance arteries in normal pregnancy and preeclampsia. Am. J. Obstet. Gynecol. 1996, 175, 1668-1674. [CrossRef]

66. Ashworth, J.R.; Warren, A.Y.; Baker, P.; Johnson, I.R. Loss of endothelium-dependent relaxation in myometrial resistance arteries in pre-eclampsia. BJOG Int. J. Obstet. Gynaecol. 1997, 104, 1152-1158. [CrossRef]

67. Ashworth, J.R.; Baker, P.N.; Warren, A.Y.; Phil, M.; Johnson, I.R. Mechanisms of Endothelium-Dependent Relaxation in Myometrial Resistance Vessels and Their Alteration in Preeclampsia. Hypertens. Pregnancy 1999, 18, 57-71. [CrossRef]

68. Svedas, E.; Nisell, H.; Vanwijk, M.J.; Nikas, Y.; Kublickiene, K.R. Endothelial dysfunction in uterine circulation in preeclampsia: Can estrogens improve it? Am. J. Obstet. Gynecol. 2002, 187, 1608-1616. [CrossRef]

69. Ong, S.S.; Moore, R.J.; Warren, A.Y.; Crocker, I.P.; Fulford, J.; Tyler, D.J.; Gowland, P.A.; Baker, P.N. Myometrial and placental artery reactivity alone cannot explain reduced placental perfusion in pre-eclampsia and intrauterine growth restriction. BJOG Int. J. Obstet. Gynaecol. 2003, 110, 909-915. [CrossRef]

70. Wareing, M.; Myers, J.E.; O’Hara, M.; Kenny, L.C.; Warren, A.Y.; Taggart, M.J.; Skillern, L.; Machin, I.; Baker, P.N. Effects of a phosphodiesterase-5 (PDE5) inhibitor on endothelium-dependent relaxation of myometrial small arteries. Am. J. Obstet. Gynecol. 2004, 190, 1283-1290. [CrossRef]

71. Luksha, L.; Luksha, N.; Kublickas, M.; Nisell, H.; Kublickiene, K. Diverse Mechanisms of Endothelium-Derived Hyperpolarizing Factor-Mediated Dilatation in Small Myometrial Arteries in Normal Human Pregnancy and Preeclampsia1. Biol. Reprod. 2010, 83, 728-735. [CrossRef]

72. Moyes, A.J.; Gray, G.A.; Denison, F.C. Bradykinin B1receptor-Mediated Vasodilation is Impaired in Myometrial Arteries from Women with Pre-Eclampsia. Hypertens. Pregnancy 2013, 33, 177-190. [CrossRef] [PubMed]

73. Mazzuca, M.Q.; Li, W.; Reslan, O.M.; Yu, P.; Mata, K.M.; Khalil, R.A. Downregulation of Microvascular Endothelial Type B Endothelin Receptor Is a Central Vascular Mechanism in Hypertensive Pregnancy. Hypertension 2014, 64, 632-643. [CrossRef] [PubMed]

74. Aljunaidy, M.M.; Morton, J.S.; Cooke, C.-L.; Davidge, S.T. Maternal vascular responses to hypoxia in a rat model of intrauterine growth restriction. Am. J. Physiol. Integr. Comp. Physiol. 2016, 311, R1068-R1075. [CrossRef] [PubMed]

75. Turan, S.; Aberdeen, G.W.; Thompson, L.P. Chronic hypoxia alters maternal uterine and fetal hemodynamics in the full-term pregnant guinea pig. Am. J. Physiol. Integr. Comp. Physiol. 2017, 313, R330-R339. [CrossRef]

76. Anderson, C.M.; Lopez, F.; Zhang, H.-Y.; Pavlish, K.; Benoit, J.N. Reduced Uteroplacental Perfusion Alters Uterine Arcuate Artery Function in the Pregnant Sprague-Dawley Rat1. Biol. Reprod. 2005, 72, 762-766. [CrossRef] [PubMed]

77. Verlohren, S.; Niehoff, M.; Hering, L.; Geusens, N.; Herse, F.; Tintu, A.N.; Plagemann, A.; Lenoble, F.; Pijnenborg, R.; Muller, M.N.; et al. Uterine Vascular Function in a Transgenic Preeclampsia Rat Model. Hypertension 2008, 51, 547-553. [CrossRef]

78. Pulgar, V.M.; Yamaleyeva, L.M.; Varagic, J.; McGee, C.M.; Bader, M.; Dechend, R.; Howlett, A.C.; Brosnihan, K.B. Increased angiotensin II contraction of the uterine artery at early gestation in a transgenic model of hypertensive pregnancy is reduced by inhibition of endocannabinoid hydrolysis. Hypertension 2014, 64, 619-625. [CrossRef]

79. Ando, J.; Yamamoto, K. Flow detection and calcium signalling in vascular endothelial cells. Cardiovasc. Res. 2013, 99, 260-268. [CrossRef] [PubMed]

80. Lu, D.; Kassab, G.S. Role of shear stress and stretch in vascular mechanobiology. J. R. Soc. Interface 2011, 8, 1379-1385. [CrossRef]

81. Mateev, S.; Sillau, A.H.; Mouser, R.; McCullough, R.E.; White, M.M.; Young, D.A.; Moore, L.G. Chronic hypoxia opposes pregnancy-induced increase in uterine artery vasodilator response to flow. Am. J. Physiol. Heart Circ. Physiol. 2003, 284, H820-H829. [CrossRef]

82. Sandoo, A.; Van Zanten, J.J.V.; Metsios, G.S.; Carroll, D.; Kitas, G. The Endothelium and Its Role in Regulating Vascular Tone. Open Cardiovasc. Med. J. 2010, 4, 302-312. [CrossRef]

83. Murad, F. Shattuck Lecture. Nitric oxide and cyclic GMP in cell signaling and drug development. N. Engl. J. Med. 2006, 355, 2003-2011. [CrossRef]

84. Narumiya, S.; Sugimoto, Y.; Ushikubi, F. Prostanoid Receptors: Structures, Properties, and Functions. Physiol. Rev. 1999, 79, 1193-1226. [CrossRef]

85. Biringer, R.G. A Review of Prostanoid Receptors: Expression, Characterization, Regulation, and Mechanism of Action. J. Cell Commun. Signal. 2020, 15, 155-184. [CrossRef]

86. Gheibi, S.; Jeddi, S.; Kashfi, K.; Ghasemi, A. Regulation of vascular tone homeostasis by NO and H2S: Implications in hypertension. Biochem. Pharmacol. 2018, 149, 42-59. [CrossRef] [PubMed]

87. Félétou, M. Endothelium-Dependent Hyperpolarization and Endothelial Dysfunction. J. Cardiovasc. Pharmacol. 2016, 67, 373-387. [CrossRef]

88. Garland, C.J.; Dora, K.A. EDH: Endothelium-Dependent Hyperpolarization and Microvascular Signalling. Acta Physiol. 2016, 219, 152-161. [CrossRef] [PubMed] 
89. Walsh, S.W. Eicosanoids in preeclampsia. Prostaglandins Leukot Essent Fat. Acids 2004, 70, 223-232. [CrossRef]

90. Toda, N.; Toda, H.; Okamura, T. Regulation of myometrial circulation and uterine vascular tone by constitutive nitric oxide. Eur. J. Pharmacol. 2013, 714, 414-423. [CrossRef] [PubMed]

91. Holwerda, K.M.; Faas, M.M.; van Goor, H.; Lely, A.T. Gasotransmitters: A solution for the therapeutic dilemma in preeclampsia? Hypertension 2013, 62, 653-659. [CrossRef]

92. Goulopoulou, S. Maternal Vascular Physiology in Preeclampsia. Hypertension 2017, 70, 1066-1073. [CrossRef] [PubMed]

93. Sutton, E.F.; Gemmel, M.; Powers, R.W. Nitric oxide signaling in pregnancy and preeclampsia. Nitric Oxide $2019,95,55-62$. [CrossRef] [PubMed]

94. Osol, G.; Ko, N.L.; Mandalà, M. Altered Endothelial Nitric Oxide Signaling as a Paradigm for Maternal Vascular Maladaptation in Preeclampsia. Curr. Hypertens. Rep. 2017, 19, 82. [CrossRef] [PubMed]

95. Nelson, S.H.; Steinsland, O.S.; Wang, Y.; Yallampalli, C.; Dong, Y.-L.; Sanchez, J.M. Increased Nitric Oxide Synthase Activity and Expression in the Human Uterine Artery During Pregnancy. Circ. Res. 2000, 87, 406-411. [CrossRef]

96. Xiao, D.; Bird, I.M.; Magness, R.R.; Longo, L.D.; Zhang, L. Upregulation of eNOS in pregnant ovine uterine arteries by chronic hypoxia. Am. J. Physiol. Heart Circ. Physiol. 2001, 280, H812-H820. [CrossRef]

97. Magness, R.R.; Sullivan, J.A.; Li, Y.; Phernetton, T.M.; Bird, I.M. Endothelial vasodilator production by uterine and systemic arteries. VI. Ovarian and pregnancy effects on eNOS and NO(x). Am. J. Physiol. Heart Circ. Physiol. 2001, 280, H1692-H1698. [CrossRef]

98. Magness, R.R.; Rosenfeld, C.R.; Hassan, A.; Shaul, P.W. Endothelial vasodilator production by uterine and systemic arteries. I. Effects of ANG II on PGI2 and NO in pregnancy. Am. J. Physiol. Heart Circ. Physiol. 1996, 270, H1914-H1923. [CrossRef]

99. Xiao, D.; Liu, Y.; Pearce, W.; Zhang, L. Endothelial nitric oxide release in isolated perfused ovine uterine arteries: Effect of pregnancy. Eur. J. Pharmacol. 1999, 367, 223-230. [CrossRef]

100. Amit, A.; Thaler, I.; Paz, Y.; Itskovitz-Eldor, J. The effect of a nitric oxide donor on Doppler flow velocity waveforms in the uterine artery during the first trimester of pregnancy. Ultrasound Obstet. Gynecol. 1998, 11, 94-98. [CrossRef]

101. Miller, S.L.; Jenkin, G.; Walker, D.W. Effect of nitric oxide synthase inhibition on the uterine vasculature of the late-pregnant ewe. Am. J. Obstet. Gynecol. 1999, 180, 1138-1145. [CrossRef]

102. Rosenfeld, C.R.; White, R.E.; Roy, T.; Cox, B.E. Calcium-Activated potassium channels and nitric oxide coregulate estrogeninduced vasodilation. Am. J. Physiol. Heart Circ. Physiol. 2000, 279, H319-H328. [CrossRef]

103. Rosenfeld, C.R.; Roy, T. Prolonged uterine artery nitric oxide synthase inhibition modestly alters basal uteroplacental vasodilation in the last third of ovine pregnancy. Am. J. Physiol. Heart Circ. Physiol. 2014, 307, H1196-H1203. [CrossRef] [PubMed]

104. Rosenfeld, C.R.; Cox, B.E.; Roy, T.; Magness, R.R. Nitric oxide contributes to estrogen-induced vasodilation of the ovine uterine circulation. J. Clin. Investig. 1996, 98, 2158-2166. [CrossRef]

105. Wight, E.; Küng, C.F.; Moreau, P.; Takase, H.; Lüscher, T.F. Chronic Blockade of Nitric Oxide Synthase and Endothelin Receptors During Pregnancy in the Rat: Effect on Reactivity of the Uterine Artery In Vitro. J. Soc. Gynecol. Investig. 1998, 5, $288-295$. [CrossRef]

106. Kublickiene, K.R.; Nisell, H.; Poston, L.; Krüger, K.; Lindblom, B. Modulation of vascular tone by nitric oxide and endothelin 1 in myometrial resistance arteries from pregnant women at term. Am. J. Obstet. Gynecol. 2000, 182, 87-93. [CrossRef]

107. Van Buren, G.A.; Yang, D.-S.; Clark, K.E. Estrogen-Induced uterine vasodilatation is antagonized by L-nitroarginine methyl ester, an inhibitor of nitric oxide synthesis. Am. J. Obstet. Gynecol. 1992, 167, 828-833. [CrossRef]

108. Stanley, J.L.; Andersson, I.J.; Hirt, C.J.; Moore, L.; Dilworth, M.; Chade, A.R.; Sibley, C.P.; Davidge, S.T.; Baker, P. Effect of the Anti-Oxidant Tempol on Fetal Growth in a Mouse Model of Fetal Growth Restriction1. Biol. Reprod. 2012, 87, 1-8. [CrossRef]

109. Kusinski, L.C.; Stanley, J.L.; Dilworth, M.R.; Hirt, C.J.; Andersson, I.J.; Renshall, L.J.; Baker, B.C.; Baker, P.N.; Sibley, C.P.; Wareing, M.; et al. eNOS Knockout Mouse as a Model of Fetal Growth Restriction with an Impaired Uterine Artery Function and Placental Transport Phenotype. Am. J. Physiol. Integr. Comp. Physiol. 2012, 303, R86-R93. [CrossRef]

110. Kulandavelu, S.; Whiteley, K.J.; Qu, D.; Mu, J.; Bainbridge, S.A.; Adamson, S.L. Endothelial Nitric Oxide Synthase Deficiency Reduces Uterine Blood Flow, Spiral Artery Elongation, and Placental Oxygenation in Pregnant Mice. Hypertension 2012, 60, 231-238. [CrossRef]

111. Rennie, M.Y.; Rahman, A.; Whiteley, K.J.; Sled, J.G.; Adamson, S.L. Site-Specific increases in utero- and fetoplacental arterial vascular resistance in eNOS-deficient mice due to impaired arterial enlargement. Biol. Reprod. 2015, 92, 48. [CrossRef]

112. Shaamash, A.; Elsonosy, E.; Zakhari, M.; Radwan, S.; El-Dien, H. Placental nitric oxide synthase (NOS) activity and nitric oxide (NO) production in normal pregnancy, pre-eclampsia and eclampsia. Int. J. Gynecol. Obstet. 2001, 72, 127-133. [CrossRef]

113. Smith-Jackson, K.; Hentschke, M.; Poli-De-Figueiredo, C.; da Costa, B.E.P.; Kurlak, L.; Pipkin, F.B.; Czajka, A.; Mistry, H. Placental expression of eNOS, iNOS and the major protein components of caveolae in women with pre-eclampsia. Placenta 2015, 36, 607-610. [CrossRef]

114. Kim, Y.; Park, H.; Lee, H.; Ha, E.; Suh, S.; Oh, S.; Yoo, H.-S. Reduced l-arginine Level and Decreased Placental eNOS Activity in Preeclampsia. Placenta 2006, 27, 438-444. [CrossRef] [PubMed]

115. Du, L.; He, F.; Kuang, L.; Tang, W.; Li, Y.; Chen, D. eNOS/iNOS And Endoplasmic Reticulum Stress-Induced Apoptosis in the Placentas of Patients with Preeclampsia. J. Hum. Hypertens. 2016, 31, 49-55. [CrossRef] 
116. Chen, J.; Gao, Q.; Jiang, L.; Feng, X.; Zhu, X.; Fan, X.; Mao, C.; Xu, Z. The NOX2-Derived reactive oxygen species damaged endothelial nitric oxide system via suppressed BKCa/SKCa in preeclampsia. Hypertens. Res. 2017, 40, 457-464. [CrossRef] [PubMed]

117. Li, F.-F.; He, M.-Z.; Xie, Y.; Wu, Y.-Y.; Yang, M.-T.; Fan, Y.; Qiao, F.-Y.; Deng, D.-R. Involvement of dysregulated IKCa and SKCa channels in preeclampsia. Placenta 2017, 58, 9-16. [CrossRef] [PubMed]

118. Shaheen, G.; Jahan, S.; Ain, Q.U.; Ullah, A.; Afsar, T.; Almajwal, A.; Alam, I.; Razak, S. Placental endothelial nitric oxide synthase expression and role of oxidative stress in susceptibility to preeclampsia in Pakistani women. Mol. Genet. Genom. Med. 2020, 8, e1019.

119. Baker, P.; Davidge, S.T.; Roberts, J.M. Plasma from Women With Preeclampsia Increases Endothelial Cell Nitric Oxide Production. Hypertension 1995, 26, 244-248. [CrossRef]

120. Davidge, S.T.; Baker, P.N.; Roberts, J.M. NOS Expression is Increased in Endothelial Cells Exposed to Plasma from Women with Preeclampsia. Am. J. Physiol. Heart Circ. Physiol. 1995, 269, H1106-H1112. [CrossRef]

121. Kao, C.K.; Morton, J.S.; Quon, A.L.; Reyes, L.M.; Lopez-Jaramillo, P.; Davidge, S.T. Mechanism of vascular dysfunction due to circulating factors in women with pre-eclampsia. Clin. Sci. 2016, 130, 539-549. [CrossRef] [PubMed]

122. Tashie, W.; Fondjo, L.A.; Owiredu, W.K.B.A.; Ephraim, R.K.D.; Asare, L.; Adu-Gyamfi, E.A.; Seidu, L. Altered Bioavailability of Nitric Oxide and L-Arginine Is a Key Determinant of Endothelial Dysfunction in Preeclampsia. BioMed Res. Int. 2020, 2020, 1-9. [CrossRef]

123. Roggensack, A.M.; Zhang, Y.; Davidge, S.T. Evidence for Peroxynitrite Formation in the Vasculature of Women with Preeclampsia. Hypertension 1999, 33, 83-89. [CrossRef] [PubMed]

124. Mitchell, B.M.; Cook, L.G.; Danchuk, S.; Puschett, J.B. Uncoupled Endothelial Nitric Oxide Synthase and Oxidative Stress in a Rat Model of Pregnancy-Induced Hypertension. Am. J. Hypertens. 2007, 20, 1297-1304. [CrossRef]

125. Guerby, P.; Tasta, O.; Swiader, A.; Pont, F.; Bujold, E.; Parant, O.; Vayssiere, C.; Salvayre, R.; Negre-Salvayre, A. Role of oxidative stress in the dysfunction of the placental endothelial nitric oxide synthase in preeclampsia. Redox Biol. 2021, 40, 101861. [CrossRef] [PubMed]

126. Noris, M.; Todeschini, M.; Cassis, P.; Pasta, F.; Cappellini, A.; Bonazzola, S.; Macconi, D.; Maucci, R.; Porrati, F.; Benigni, A.; et al. 1-Arginine Depletion in Preeclampsia Orients Nitric Oxide Synthase Toward Oxidant Species. Hypertension 2004, 43, 614-622. [CrossRef]

127. Sankaralingam, S.; Xu, H.; Davidge, S.T. Arginase contributes to endothelial cell oxidative stress in response to plasma from women with preeclampsia. Cardiovasc. Res. 2009, 85, 194-203. [CrossRef] [PubMed]

128. Lorca, R.A.; Lane, S.L.; Bales, E.S.; Nsier, H.; Yi, H.; Donnelly, M.A.; Euser, A.G.; Julian, C.G.; Moore, L.G. High Altitude Reduces NO-Dependent Myometrial Artery Vasodilator Response During Pregnancy. Hypertension 2019, 73, 1319-1326. [CrossRef]

129. Polhemus, D.J.; Lefer, D.J. Emergence of Hydrogen Sulfide as an Endogenous Gaseous Signaling Molecule in Cardiovascular Disease. Circ. Res. 2014, 114, 730-737. [CrossRef] [PubMed]

130. Sheibani, L.; Lechuga, T.J.; Zhang, H.; Hameed, A.; Wing, D.A.; Kumar, S.; Rosenfeld, C.R.; Chen, D.-B. Augmented H2S production via cystathionine-beta-synthase upregulation plays a role in pregnancy-associated uterine vasodilation. Biol. Reprod. 2017, 96, 664-672. [CrossRef]

131. Lechuga, T.J.; Qi, Q.R.; Magness, R.R.; Chen, D.B. Ovine uterine artery hydrogen sulfide biosynthesis in vivo: Effects of ovarian cycle and pregnancydagger. Biol. Reprod. 2019, 100, 1630-1636. [CrossRef] [PubMed]

132. Bok, R.; Guerra, D.D.; Lorca, R.A.; Wennersten, S.A.; Harris, P.S.; Rauniyar, A.K.; Stabler, S.P.; MacLean, K.N.; Roede, J.R.; Brown, L.D.; et al. Cystathionine gamma-lyase promotes estrogen-stimulated uterine artery blood flow via glutathione homeostasis. Redox Biol. 2021, 40, 101827. [CrossRef]

133. Cindrova-Davies, T.; Herrera, E.A.; Niu, Y.; Kingdom, J.; Giussani, D.A.; Burton, G.J. Reduced cystathionine gamma-lyase and increased miR-21 expression are associated with increased vascular resistance in growth-restricted pregnancies: Hydrogen sulfide as a placental vasodilator. Am. J. Pathol. 2013, 182, 1448-1458. [CrossRef]

134. Holwerda, K.; Bos, E.; Rajakumar, A.; Ris-Stalpers, C.; van Pampus, M.; Timmer, A.; Erwich, J.; Faas, M.; van Goor, H.; Lely, A. Hydrogen sulfide producing enzymes in pregnancy and preeclampsia. Placenta 2012, 33, 518-521. [CrossRef] [PubMed]

135. Wang, K.; Ahmad, S.; Cai, M.; Rennie, J.; Fujisawa, T.; Crispi, F.; Baily, J.; Miller, M.R.; Cudmore, M.; Hadoke, P.W.; et al. Dysregulation of hydrogen sulfide producing enzyme cystathionine gamma-lyase contributes to maternal hypertension and placental abnormalities in preeclampsia. Circulation 2013, 127, 2514-2522. [CrossRef] [PubMed]

136. Saif, J.; Ahmad, S.; Rezai, H.; Litvinova, K.; Sparatore, A.; Alzahrani, F.A.; Wang, K.; Ahmed, A. Hydrogen sulfide releasing molecule MZe786 inhibits soluble Flt-1 and prevents preeclampsia in a refined RUPP mouse model. Redox Biol. 2021, $38,101814$. [CrossRef]

137. Janowiak, M.A.; Magness, R.R.; Habermehl, D.A.; Bird, I.M. Pregnancy Increases Ovine Uterine Artery Endothelial Cyclooxygenase-1 Expression. Endocrinology 1998, 139, 765-771. [CrossRef]

138. Di, T.; Sullivan, J.A.; Rupnow, H.L.; Magness, R.R.; Bird, I.M. Pregnancy Induces Expression of cPLA2 in Ovine Uterine Artery but Not Systemic Artery Endothelium. J. Soc. Gynecol. Investig. 1999, 6, 301-306. [CrossRef]

139. Magness, R.R.; Shideman, C.R.; Habermehl, D.A.; Sullivan, J.A.; Bird, I.M. Endothelial vasodilator production by uterine and systemic arteries. V. Effects of ovariectomy, the ovarian cycle, and pregnancy on prostacyclin synthase expression. Prostaglandins Other Lipid Mediat. 2000, 60, 103-118. [CrossRef] 
140. Magness, R.R.; Rosenfeld, C.R.; Faucher, D.J.; Mitchell, M. Uterine prostaglandin production in ovine pregnancy: Effects of angiotensin II and indomethacin. Am. J. Physiol. Heart Circ. Physiol. 1992, 263, H188-H197. [CrossRef] [PubMed]

141. Gerber, J.G.; Payne, N.A.; Murphy, R.C.; Nies, A.S. Prostacyclin produced by the pregnant uterus in the dog may act as a circulating vasodepressor substance. J. Clin. Investig. 1981, 67, 632-636. [CrossRef]

142. Clark, K.E.; Harrington, D.J. Effect of the prostacyclin synthetase inhibitor tranylcypromine on uterine blood flow in pregnancy. Prostaglandins 1982, 23, 227-236. [CrossRef]

143. Khan, I.; Al-Yatama, M.; Nandakumaran, M. Expression of the Na -H exchanger isoform-1 and cyclooxygenases in human placentas: Their implications in preeclampsia. IUBMB Life 1999, 47, 715-722. [CrossRef]

144. Börekçi, B.; Aksoy, H.; Toker, A.; Özkan, A. Placental tissue cyclo-oxygenase 1 and 2 in pre-eclamptic and normal pregnancy. Int. J. Gynecol. Obstet. 2006, 95, 127-131. [CrossRef]

145. Hu, S.; Li, J.; Tong, M.; Li, Q.; Chen, Y.; Lu, H.; Wang, Y.; Min, L. MicroRNA1443p may participate in the pathogenesis of preeclampsia by targeting Cox2. Mol Med Rep 2019, 19, 4655-4662. [PubMed]

146. Fitzgerald, D.J.; Entman, S.S.; Mulloy, K.; Fitzgerald, G.A. Decreased prostacyclin biosynthesis preceding the clinical manifestation of pregnancy-induced hypertension. Circulation 1987, 75, 956-963. [CrossRef]

147. Walsh, S.W. Preeclampsia: An imbalance in placental prostacyclin and thromboxane Production. Am. J. Obstet. Gynecol. 1985, 152, 335-340. [CrossRef]

148. Remuzzi, G.; Marchesi, D.; Zoja, C.; Muratore, D.; Mecca, G.; Misiani, R.; Rossi, E.; Barbato, M.; Capetta, P.; Donati, M.B.; et al. Reduced umbilical and placental vascular prostacyclin in severe pre-eclampsia. Prostaglandins 1980, 20, 105-110. [CrossRef]

149. Suzuki, Y.; Hattori, T.; Kajikuri, J.; Yamamoto, T.; Suzumori, K.; Itoh, T. Reduced function of endothelial prostacyclin in human omental resistance arteries in pre-eclampsia. J. Physiol. 2002, 545, 269-277. [CrossRef] [PubMed]

150. Gokina, N.I.; Kuzina, O.Y.; Vance, A.M. Augmented EDHF signaling in rat uteroplacental vasculature during late pregnancy. Am. J. Physiol. Heart Circ. Physiol. 2010, 299, H1642-H1652. [CrossRef]

151. Mazzuca, M.Q.; Tare, M.; Parkington, H.C.; Dragomir, N.M.; Parry, L.J.; Wlodek, M.E. Uteroplacental insufficiency programmes vascular dysfunction in non-pregnant rats: Compensatory adaptations in pregnancy. J. Physiol. 2012, 590, 3375-3388. [CrossRef]

152. Feletou, M.; Vanhoutte, P.M. Endothelium-Derived hyperpolarizing factor: Where are we now? Arterioscler. Thromb. Vasc. Biol. 2006, 26, 1215-1225. [CrossRef] [PubMed]

153. Kenny, L.; Baker, P.; Kendall, D.A.; Randall, M.D.; Dunn, W.R. The role of gap junctions in mediating endothelium-dependent responses to bradykinin in myometrial small arteries isolated from pregnant women. Br. J. Pharmacol. 2002, 136, 1085-1088. [CrossRef]

154. Luksha, L.; Nisell, H.; Luksha, N.; Kublickas, M.; Hultenby, K.; Kublickiene, K. Endothelium-derived hyperpolarizing factor in preeclampsia: Heterogeneous contribution, mechanisms, and morphological prerequisites. Am. J. Physiol. Integr. Comp. Physiol. 2008, 294, R510-R519. [CrossRef] [PubMed]

155. Zhu, R.; Hu, X.Q.; Xiao, D.; Yang, S.; Wilson, S.M.; Longo, L.D.; Zhang, L. Chronic hypoxia inhibits pregnancy-induced upregulation of SKCa channel expression and function in uterine arteries. Hypertension 2013, 62, 367-374. [CrossRef]

156. Choi, S.; Kim, J.A.; Na, H.-Y.; Park, S.; Han, K.-H.; Kim, Y.J.; Suh, S.H. NADPH Oxidase 2-Derived Superoxide Downregulates Endothelial KCa3.1 in Preeclampsia. Free Radic. Biol. Med. 2013, 57, 10-21. [CrossRef] [PubMed]

157. Abbassi-Ghanavati, M.; Greer, L.G.; Cunningham, F.G. Pregnancy and Laboratory Studies: A Reference Table for Clinicians. Obstet. Gynecol. 2010, 115, 868-869. [CrossRef]

158. Chang, K.; Lubo, Z. Review article: Steroid hormones and uterine vascular adaptation to pregnancy. Reprod. Sci. 2008, 15, 336-348. [CrossRef]

159. Pastore, M.B.; Jobe, S.O.; Ramadoss, J.; Magness, R.R. Estrogen receptor-alpha and estrogen receptor-beta in the uterine vascular endothelium during pregnancy: Functional implications for regulating uterine blood flow. Semin. Reprod. Med. 2012, $30,46-61$.

160. Hu, X.-Q.; Song, R.; Zhang, L. Effect of Oxidative Stress on the Estrogen-NOS-NO-KCa Channel Pathway in Uteroplacental Dysfunction: Its Implication in Pregnancy Complications. Oxidative Med. Cell. Longev. 2019, 2019, 1-19. [CrossRef] [PubMed]

161. Mandalà, M. Influence of Estrogens on Uterine Vascular Adaptation in Normal and Preeclamptic Pregnancies. Int. J. Mol. Sci. 2020, 21, 2592. [CrossRef]

162. Bai, J.; Qi, Q.-R.; Li, Y.; Day, R.; Makhoul, J.; Magness, R.R.; Chen, D.-B. Estrogen Receptors and Estrogen-Induced Uterine Vasodilation in Pregnancy. Int. J. Mol. Sci. 2020, 21, 4349. [CrossRef] [PubMed]

163. Magness, R.R.; Rosenfeld, C.R. Local and systemic estradiol-17 beta: Effects on uterine and systemic vasodilation. Am. J. Physiol. Content 1989, 256, E536-E542. [CrossRef]

164. Magness, R.R.; Parker, C.R.; Rosenfeld, C.R. Systemic and uterine responses to chronic infusion of estradiol-17 beta. Am. J. Physiol. Metab. 1993, 265, E690-E698. [CrossRef] [PubMed]

165. Magness, R.R.; Phernetton, T.M.; Gibson, T.C.; Chen, D.B. Uterine blood flow responses to ICI 182780 in ovariectomized oestradiol-17beta-treated, intact follicular and pregnant sheep. J. Physiol. 2005, 565, 71-83. [CrossRef]

166. Corcoran, J.J.; Nicholson, C.; Sweeney, M.; Charnock, J.C.; Robson, S.C.; Westwood, M.; Taggart, M.J. Human uterine and placental arteries exhibit tissue-specific acute responses to 17beta-estradiol and estrogen-receptor-specific agonists. Mol. Hum. Reprod. 2014, 20, 433-441. [CrossRef] [PubMed] 
167. Tropea, T.; De Francesco, E.M.; Rigiracciolo, D.C.; Maggiolini, M.; Wareing, M.; Osol, G.; Mandalà, M. Pregnancy Augments G Protein Estrogen Receptor (GPER) Induced Vasodilation in Rat Uterine Arteries via the Nitric Oxide-cGMP Signaling Pathway. PLoS ONE 2015, 10, e0141997. [CrossRef]

168. Scott, P.-A.; Tremblay, A.; Brochu, M.; St-Louis, J. Vasorelaxant action of $17 \beta$-estradiol in rat uterine arteries: Role of nitric oxide synthases and estrogen receptors. Am. J. Physiol. Heart Circ. Physiol. 2007, 293, H3713-H3719. [CrossRef]

169. Berkane, N.; Liere, P.; Oudinet, J.-P.; Hertig, A.; Lefèvre, G.; Pluchino, N.; Schumacher, M.; Chabbert-Buffet, N. From Pregnancy to Preeclampsia: A Key Role for Estrogens. Endocr. Rev. 2017, 38, 123-144. [CrossRef] [PubMed]

170. Hertig, A.; Liere, P.; Chabbert-Buffet, N.; Fort, J.; Pianos, A.; Eychenne, B.; Cambourg, A.; Schumacher, M.; Berkane, N.; Lefevre, G.; et al. Steroid profiling in preeclamptic women: Evidence for aromatase deficiency. Am. J. Obstet. Gynecol. 2010, 203, 477.e1-477.e9. [CrossRef]

171. Jobe, S.O.; Tyler, C.T.; Magness, R.R. Aberrant Synthesis, Metabolism, and Plasma Accumulation of Circulating Estrogens and Estrogen Metabolites in Preeclampsia Implications for Vascular Dysfunction. Hypertension 2013, 61, 480-487. [CrossRef] [PubMed]

172. Wan, J.; Hu, Z.; Zeng, K.; Yin, Y.; Zhao, M.; Chen, M.; Chen, Q. The reduction in circulating levels of estrogen and progesterone in women with preeclampsia. Pregnancy Hypertens. 2017, 11, 18-25. [CrossRef] [PubMed]

173. Sobrevilla, L.A.; Romero, I.; Kruger, F.; Whittembury, J. Low estrogen excretion during pregnancy at high altitude. Am. J. Obstet. Gynecol. 1968, 102, 828-833. [CrossRef]

174. Zamudio, S.; Leslie, K.; White, M.; Hagerman, D.D.; Moore, L.G. Low Serum Estradiol and High Serum Progesterone Concentrations Characterize Hypertensive Pregnancies at High Altitude. J. Soc. Gynecol. Investig. 1994, 1, 197-205. [CrossRef]

175. Berkane, N.; Liere, P.; Lefevre, G.; Alfaidy, N.; Nahed, R.A.; Vincent, J.; Oudinet, J.-P.; Pianos, A.; Cambourg, A.; Rozenberg, P.; et al. Abnormal steroidogenesis and aromatase activity in preeclampsia. Placenta 2018, 69, 40-49. [CrossRef]

176. Pérez-Sepúlveda, A.; Monteiro, L.J.; Dobierzewska, A.; España-Perrot, P.P.; Venegas-Araneda, P.; Guzmán-Rojas, A.M.; González, M.I.; Palominos-Rivera, M.; Irarrazabal, C.E.; Figueroa-Diesel, H.; et al. Placental Aromatase Is Deficient in Placental Ischemia and Preeclampsia. PLoS ONE 2015, 10, e0139682. [CrossRef] [PubMed]

177. Jiang, B.; Mendelson, C. USF1 and USF2 Mediate Inhibition of Human Trophoblast Differentiation and CYP19 Gene Expression by Mash-2 and Hypoxia. Mol. Cell. Biol. 2003, 23, 6117-6128. [CrossRef]

178. Murphy, E. Estrogen Signaling and Cardiovascular Disease. Circ. Res. 2011, 109, 687-696. [CrossRef]

179. Byers, M.J.; Zangl, A.; Phernetton, T.M.; Lopez, G.; Chen, D.B.; Magness, R.R. Endothelial vasodilator production by ovine uterine and systemic arteries: Ovarian steroid and pregnancy control of ERalpha and ERbeta levels. J. Physiol. 2005, 565, 85-99. [CrossRef]

180. Chang, K.; Xiao, D.; Huang, X.; Xue, Z.; Yang, S.; Longo, L.D.; Zhang, L. Chronic Hypoxia Inhibits Sex Steroid Hormone-Mediated Attenuation of Ovine Uterine Arterial Myogenic Tone in Pregnancy. Hypertension 2010, 56, 750-757. [CrossRef]

181. Chen, M.; Xiao, D.; Hu, X.Q.; Dasgupta, C.; Yang, S.; Zhang, L. Hypoxia Represses ER-alpha Expression and Inhibits EstrogenInduced Regulation of $\mathrm{Ca}^{2+}$-Activated $\mathrm{K}^{+}$Channel Activity and Myogenic Tone in Ovine Uterine Arteries: Causal Role of DNA Methylation. Hypertension 2015, 66, 44-51. [CrossRef]

182. Lambertini, E.; Penolazzi, L.; Giordano, S.; Del Senno, L.; Piva, R. Expression of the human oestrogen receptor-alpha gene is regulated by promoter F in MG-63 osteoblastic cells. Biochem. J. 2003, 372, 831-839. [CrossRef]

183. Dasgupta, C.; Chen, M.; Zhang, H.; Yang, S.; Zhang, L. Chronic Hypoxia During Gestation Causes Epigenetic Repression of the Estrogen Receptor- $\alpha$ Gene in Ovine Uterine Arteries via Heightened Promoter Methylation. Hypertension 2012, 60, 697-704. [CrossRef] [PubMed]

184. Hu, X.Q.; Dasgupta, C.; Chen, M.; Xiao, D.; Huang, X.; Han, L.; Yang, S.; Xu, Z.; Zhang, L. Pregnancy Reprograms LargeConductance $\mathrm{Ca}(2+)$-Activated $\mathrm{K}(+)$ Channel in Uterine Arteries: Roles of Ten-Eleven Translocation Methylcytosine Dioxygenase 1-Mediated Active Demethylation. Hypertension 2017, 69, 1181-1191. [CrossRef]

185. Park, M.; Park, K.; Lee, J.; Shin, Y.Y.; An, S.; Kang, S.S.; Cho, W.; An, B.; Kim, S.C. The expression and activation of sex steroid receptors in the preeclamptic placenta. Int. J. Mol. Med. 2018, 41, 2943-2951. [CrossRef] [PubMed]

186. Lan, K.-C.; Lai, Y.-J.; Cheng, H.-H.; Tsai, N.-C.; Su, Y.-T.; Tsai, C.-C.; Hsu, T.-Y. Levels of sex steroid hormones and their receptors in women with preeclampsia. Reprod. Biol. Endocrinol. 2020, 18, 1-7. [CrossRef]

187. Hu, X.-Q.; Chen, M.; Dasgupta, C.; Xiao, D.; Huang, X.; Yang, S.; Zhang, L. Chronic hypoxia upregulates DNA methyltransferase and represses large conductance $\mathrm{Ca}^{2+}$-activated $\mathrm{K}^{+}$channel function in ovine uterine arteries. Biol. Reprod. 2017, 96, 424-434. [CrossRef] [PubMed]

188. Hu, X.-Q.; Dasgupta, C.; Xiao, D.; Huang, X.; Yang, S.; Zhang, L. MicroRNA-210 Targets Ten-Eleven Translocation Methylcytosine Dioxygenase 1 and Suppresses Pregnancy-Mediated Adaptation of Large Conductance $\mathrm{Ca}^{2+}$-Activated $\mathrm{K}^{+}$Channel Expression and Function in Ovine Uterine Arteries. Hypertension 2017, 70, 601-612. [CrossRef]

189. Hu, X.-Q.; Dasgupta, C.; Xiao, J.; Yang, S.; Zhang, L. Long-term high altitude hypoxia during gestation suppresses large conductance $\mathrm{Ca}^{2+}$-activated $\mathrm{K}^{+}$channel function in uterine arteries: A causal role for microRNA-210. J. Physiol. 2018, 596, 5891-5906. [CrossRef]

190. Feng, X.; Zhou, L.; Mao, X.; Tong, C.; Chen, X.; Zhao, D.; Baker, P.N.; Xia, Y.; Zhang, H. Association of a Reduction of G-protein Coupled Receptor 30 Expression and the Pathogenesis of Preeclampsia. Mol. Med. Rep. 2017, 16, 5997-6003. [CrossRef]

191. Pastore, M.B.; Talwar, S.; Conley, M.R.; Magness, R.R. Identification of Differential ER-Alpha Versus ER-Beta Mediated Activation of eNOS in Ovine Uterine Artery Endothelial Cells1. Biol. Reprod. 2016, 94, 139. [CrossRef] [PubMed] 
192. Salhab, W.A.; Shaul, P.W.; Cox, B.E.; Rosenfeld, C.R. Regulation of types I and III NOS in ovine uterine arteries by daily and acute estrogen exposure. Am. J. Physiol. Heart Circ. Physiol. 2000, 278, H2134-H2142. [CrossRef]

193. Rupnow, H.L.; Phernetton, T.M.; Shaw, C.E.; Modrick, M.L.; Bird, I.M.; Magness, R.R. Endothelial vasodilator production by uterine and systemic arteries. VII. Estrogen and progesterone effects on eNOS. Am. J. Physiol. Heart Circ. Physiol. 2001, 280, H1699-H1705. [CrossRef] [PubMed]

194. Rosenfeld, C.R.; Chen, C.; Roy, T.; Liu, X.T. Estrogen Selectively Up-Regulates eNOS and nNOS in Reproductive Arteries by Transcriptional Mechanisms. J. Soc. Gynecol. Investig. 2003, 10, 205-215. [CrossRef]

195. Hayashi, T.; Yamada, K.; Esaki, T.; Kuzuya, M.; Satake, S.; Ishikawa, T.; Hidaka, H.; Iguchi, A. Estrogen Increases Endothelial Nitric Oxide by a Receptor Mediated System. Biochem. Biophys. Res. Commun. 1995, 214, 847-855. [CrossRef]

196. Lechuga, T.J.; Zhang, H.H.; Sheibani, L.; Karim, M.; Jia, J.; Magness, R.R.; Rosenfeld, C.R.; Chen, D.B. Estrogen Replacement Therapy in Ovariectomized Nonpregnant Ewes Stimulates Uterine Artery Hydrogen Sulfide Biosynthesis by Selectively UpRegulating Cystathionine beta-Synthase Expression. Endocrinology 2015, 156, 2288-2298. [CrossRef]

197. Lechuga, T.J.; Qi, Q.R.; Kim, T.; Magness, R.R.; Chen, D.B. E2beta stimulates ovine uterine artery endothelial cell H2S production in vitro by estrogen receptor-dependent upregulation of cystathionine beta-synthase and cystathionine gamma-lyase expressiondagger. Biol. Reprod. 2019, 100, 514-522. [CrossRef]

198. Lechuga, T.J.; Bilg, A.K.; Patel, B.A.; Nguyen, N.A.; Qi, Q.R.; Chen, D.B. Estradiol-17beta stimulates H2 S biosynthesis by ER-dependent CBS and CSE transcription in uterine artery smooth muscle cells in vitro. J. Cell Physiol. 2019, 234, 9264-9273. [CrossRef]

199. Sobrino, A.; Oviedo, P.J.; Novella, S.; Laguna-Fernandez, A.; Bueno, C.; Garcia-Perez, M.A.; Tarin, J.J.; Cano, A.; Hermenegildo, C. Estradiol selectively stimulates endothelial prostacyclin production through estrogen receptor- $\alpha$. J. Mol. Endocrinol. 2010, 44, 237-246. [CrossRef]

200. Jobe, S.O.; Ramadoss, J.; Wargin, A.J.; Magness, R.R. Estradiol-17beta and its cytochrome P450- and catechol-O-methyltransferasederived metabolites selectively stimulate production of prostacyclin in uterine artery endothelial cells: Role of estrogen receptoralpha versus estrogen receptor-beta. Hypertension 2013, 61, 509-518. [CrossRef]

201. Burger, N.Z.; Kuzina, O.Y.; Osol, G.; Gokina, N.I. Estrogen replacement enhances EDHF-mediated vasodilation of mesenteric and uterine resistance arteries: Role of endothelial cell Ca ${ }^{2+}$. Am. J. Physiol. Endocrinol. Metab. 2009, 296, E503-E512. [CrossRef] [PubMed]

202. Mishra, J.S.; Gopalakrishnan, K.; Kumar, S. Pregnancy upregulates angiotensin type 2 receptor expression and increases blood flow in uterine arteries of rats. Biol. Reprod. 2018, 99, 1091-1099. [CrossRef] [PubMed]

203. Mishra, J.S.; Te Riele, G.M.; Qi, Q.R.; Lechuga, T.J.; Gopalakrishnan, K.; Chen, D.B.; Kumar, S. Estrogen Receptor-beta Mediates Estradiol-Induced Pregnancy-Specific Uterine Artery Endothelial Cell Angiotensin Type-2 Receptor Expression. Hypertension 2019, 74, 967-974. [CrossRef]

204. Pluger, S.; Faulhaber, J.; Furstenau, M.; Lohn, M.; Waldschutz, R.; Gollasch, M.; Haller, H.; Luft, F.C.; Ehmke, H.; Pongs, O. Mice with disrupted BK channel beta1 subunit gene feature abnormal $\mathrm{Ca}(2+)$ spark/STOC coupling and elevated blood pressure. Circ. Res. 2000, 87, E53-E60. [CrossRef] [PubMed]

205. Nelson, M.T.; Cheng, H.; Rubart, M.; Santana, L.F.; Bonev, A.D.; Knot, H.J.; Lederer, W.J. Relaxation of Arterial Smooth Muscle by Calcium Sparks. Science 1995, 270, 633-637. [CrossRef]

206. Jaggar, J.H.; Wellman, G.C.; Heppner, T.J.; Porter, V.; Perez, G.; Gollasch, M.; Kleppisch, T.; Rubart, M.; Stevenson, A.S.; Lederer, W.J.; et al. $\mathrm{Ca}^{2+}$ channels, ryanodine receptors and $\mathrm{Ca}^{2+}$-activated $\mathrm{K}^{+}$channels: A functional unit for regulating arterial tone. Acta Physiol. Scand. 1998, 164, 577-587. [CrossRef] [PubMed]

207. Hu, X.-Q.; Song, R.; Romero, M.; Dasgupta, C.; Huang, X.; Holguin, M.A.; Williams, V.; Xiao, D.; Wilson, S.M.; Zhang, L. Pregnancy Increases $\mathrm{Ca}^{2+}$ Sparks/Spontaneous Transient Outward Currents and Reduces Uterine Arterial Myogenic Tone. Hypertension 2019, 73, 691-702. [CrossRef]

208. Song, R.; Hu, X.-Q.; Romero, M.; Holguin, M.A.; Kagabo, W.; Xiao, D.; Wilson, S.M.; Zhang, L. Ryanodine receptor subtypes regulate $\mathrm{Ca}^{2+}$ sparks/spontaneous transient outward currents and myogenic tone of uterine arteries in pregnancy. Cardiovasc. Res. 2020, 117, 792-804. [CrossRef]

209. Nagar, D.; Liu, X.T.; Rosenfeld, C.R. Estrogen regulates $\beta$-subunit expression in $\mathrm{Ca}(2+)$-activated $\mathrm{K}(+)$ channels in arteries from reproductive tissues. Am. J. Physiol. Heart Circ. Physiol. 2005, 289, H1417-H1427. [CrossRef]

210. Rosenfeld, C.R.; Liu, X.T.; DeSpain, K. Pregnancy modifies the large conductance $\mathrm{Ca}^{2+}$-activated $\mathrm{K}^{+}$channel and cGMP-dependent signaling pathway in uterine vascular smooth muscle. Am. J. Physiol. Heart Circ. Physiol. 2009, 296, H1878-H1887. [CrossRef]

211. Rosenfeld, C.R.; Cornfield, D.N.; Roy, T. Ca(2+)-activated $\mathrm{K}(+)$ channels modulate basal and $\mathrm{E}(2)$ beta-induced rises in uterine blood flow in ovine pregnancy. Am. J. Physiol. Heart Circ. Physiol. 2001, 281, H422-H431. [CrossRef] [PubMed]

212. Rosenfeld, C.R.; Roy, T.; DesPain, K.; Cox, B.E. Large-Conductance $\mathrm{Ca}^{2+}$-Dependent $\mathrm{K}^{+}$Channels Regulate Basal Uteroplacental Blood Flow in Ovine Pregnancy. J. Soc. Gynecol. Investig. 2005, 12, 402-408. [CrossRef]

213. Lorca, R.A.; Wakle-Prabagaran, M.; Freeman, W.E.; Pillai, M.K.; England, S.K. The large-conductance voltage- and Ca(2+)activated $\mathrm{K}(+)$ channel and its gamma1-subunit modulate mouse uterine artery function during pregnancy. J. Physiol. 2018, 596, 1019-1033. [CrossRef] [PubMed]

214. Rosenfeld, C.R.; Word, R.A.; DesPain, K.; Liu, X.-T. Large Conductance $\mathrm{Ca}^{2+}$-Activated $\mathrm{K}^{+}$Channels Contribute to Vascular Function in Nonpregnant Human Uterine Arteries. Reprod. Sci. 2008, 15, 651-660. [CrossRef] [PubMed] 
215. Li, Y.; Bai, J.; Yang, Y.-H.; Hoshi, N.; Chen, D.-B. Hydrogen Sulfide Relaxes Human Uterine Artery via Activating Smooth Muscle $\mathrm{BK}_{\mathrm{Ca}}$ Channels. Antioxidants 2020, 9, 1127. [CrossRef]

216. Valverde, M.A.; Rojas, P.; Amigo, J.; Cosmelli, D.; Orio, P.; Bahamonde, M.I.; Mann, G.E.; Vergara, C.; Latorre, R. Acute activation of Maxi-K channels (hSlo) by estradiol binding to the beta subunit. Science 1999, 285, 1929-1931. [CrossRef] [PubMed]

217. De Wet, H.; Allen, M.; Holmes, C.; Stobbart, M.; Lippiat, J.D.; Callaghan, R. Modulation of the BK channel by estrogens: Examination at single channel level. Mol. Membr. Biol. 2006, 23, 420-429. [CrossRef]

218. Rosenfeld, C.R.; Hynan, L.S.; Liu, X.-T.; Roy, T. Large Conductance $\mathrm{Ca}^{2+}$-Activated $\mathrm{K}^{+}$Channels Modulate Uterine $\alpha 1$-Adrenergic Sensitivity in Ovine Pregnancy. Reprod. Sci. 2013, 21, 456-464. [CrossRef]

219. Dimitropoulou, C.; White, R.E.; Fuchs, L.; Zhang, H.; Catravas, J.D.; Carrier, G.O. Angiotensin II Relaxes Microvessels Via the AT 2 Receptor and $\mathrm{Ca}^{2+}$-Activated $\mathrm{K}^{+}$(BK Ca) Channels. Hypertension 2001, 37, 301-307. [CrossRef]

220. Xiao, D.; Zhu, R.; Zhang, L. Gestational Hypoxia Up-regulates Protein Kinase C and Inhibits Calcium-Activated Potassium Channels in Ovine Uterine Arteries. Int. J. Med. Sci. 2014, 11, 886-892. [CrossRef]

221. He, M.; Li, F.; Yang, M.; Fanfan, L.; Beejadhursing, R.; Xie, Y.; Mengzhou, H.; Deng, D. Impairment of BKca channels in human placental chorionic plate arteries is potentially relevant to the development of preeclampsia. Hypertens. Res. 2017, 41, 126-134. [CrossRef]

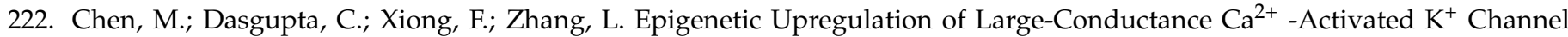
Expression in Uterine Vascular Adaptation to Pregnancy. Hypertension 2014, 64, 610-618. [CrossRef]

223. Hu, X.-Q.; Song, R.; Romero, M.; Dasgupta, C.; Min, J.; Hatcher, D.; Xiao, D.; Blood, A.; Wilson, S.M.; Zhang, L. Gestational Hypoxia Inhibits Pregnancy-Induced Upregulation of $\mathrm{Ca}^{2+}$ Sparks and Spontaneous Transient Outward Currents in Uterine Arteries Via Heightened Endoplasmic Reticulum/Oxidative Stress. Hypertension 2020, 76, 930-942. [CrossRef]

224. Soleymanlou, N.; Jurisica, I.; Nevo, O.; Ietta, F.; Zhang, X.; Zamudio, S.; Post, M.; Caniggia, I. Molecular Evidence of Placental Hypoxia in Preeclampsia. J. Clin. Endocrinol. Metab. 2005, 90, 4299-4308. [CrossRef]

225. Rajakumar, A.; Brandon, H.M.; Daftary, A.; Ness, R.; Conrad, K.P. Evidence for the functional activity of hypoxia-inducible transcription factors overexpressed in preeclamptic placentae. Placenta 2004, 25, 763-769. [CrossRef]

226. Xiao, D.; Hu, X.-Q.; Huang, X.; Zhou, J.; Wilson, S.; Yang, S.; Zhang, L. Chronic Hypoxia during Gestation Enhances Uterine Arterial Myogenic Tone via Heightened Oxidative Stress. PLoS ONE 2013, 8, e73731. [CrossRef]

227. Watson, C.J.; Collier, P.; Tea, I.; Neary, R.; Watson, J.A.; Robinson, C.; Phelan, D.; Ledwidge, M.; McDonald, K.; McCann, A.; et al. Hypoxia-Induced epigenetic modifications are associated with cardiac tissue fibrosis and the development of a myofibroblast-like phenotype. Hum. Mol. Genet. 2013, 23, 2176-2188. [CrossRef]

228. Enquobahrie, D.A.; Abetew, D.F.; Sorensen, T.K.; Willoughby, D.; Chidambaram, K.; Williams, M.A. Placental microRNA expression in pregnancies complicated by preeclampsia. Am. J. Obstet. Gynecol. 2011, 204, 178.e12-178.e21. [CrossRef] [PubMed]

229. Muralimanoharan, S.; Maloyan, A.; Mele, J.; Guo, C.; Myatt, L. MIR-210 Modulates Mitochondrial Respiration in Placenta with Preeclampsia. Placenta 2012, 33, 816-823. [CrossRef] [PubMed]

230. Yung, H.W.; Cox, M.; van Patot, M.T.; Burton, G.J. Evidence of endoplasmic reticulum stress and protein synthesis inhibition in the placenta of non-native women at high altitude. FASEB J. 2012, 26, 1970-1981. [CrossRef]

231. Zhu, R.; Huang, X.; Hu, X.-Q.; Xiao, D.; Zhang, L. Gestational Hypoxia Increases Reactive Oxygen Species and Inhibits Steroid Hormone-Mediated Upregulation of $\mathrm{Ca}^{2+}$-Activated $\mathrm{K}^{+}$Channel Function in Uterine Arteries. Hypertension 2014, 64, 415-422. [CrossRef]

232. Hu, X.-Q.; Huang, X.; Xiao, D.; Zhang, L. Direct effect of chronic hypoxia in suppressing large conductance $\mathrm{Ca}^{2+}$-activated $\mathrm{K}^{+}$ channel activity in ovine uterine arteries via increasing oxidative stress. J. Physiol. 2015, 594, 343-356. [CrossRef] [PubMed]

233. Mattheson, H.; Veerbeek, J.H.W.; Charnock-Jones, D.S.; Burton, G.J.; Yung, H.W. Morphological and molecular changes in the murine placenta exposed to normobaric hypoxia throughout pregnancy. J. Physiol. 2015, 594, 1371-1388. [CrossRef] [PubMed]

234. Hu, X.-Q.; Dasgupta, C.; Song, R.; Romero, M.; Wilson, S.M.; Zhang, L. MicroRNA-210 Mediates Hypoxia-Induced Repression of Spontaneous Transient Outward Currents in Sheep Uterine Arteries during Gestation. Hypertension 2021, 77, $1412-1427$. [CrossRef]

235. Sun, W.-T.; Wang, X.-C.; Mak, S.-K.; He, G.-W.; Liu, X.-C.; Underwood, M.J.; Yang, Q. Activation of PERK branch of ER stress mediates homocysteine-induced BKCa channel dysfunction in coronary artery via FoxO3a-dependent regulation of atrogin-1. Oncotarget 2017, 8, 51462-51477. [CrossRef] [PubMed]

236. Munzel, T.; Feil, R.; Mulsch, A.; Lohmann, S.M.; Hofmann, F.; Walter, U. Physiology and pathophysiology of vascular signaling controlled by guanosine 3',5'-cyclic monophosphate-dependent protein kinase. Circulation 2003, 108, 2172-2183. [CrossRef]

237. Ringvold, H.; Khalil, R. Protein Kinase C as Regulator of Vascular Smooth Muscle Function and Potential Target in Vascular Disorders. Adv. Pharmacol. 2017, 78, 203-301. [CrossRef] [PubMed]

238. Feil, R.; Lohmann, S.M.; de Jonge, H.; Walter, U.; Hofmann, F. Cyclic GMP-Dependent protein kinases and the cardiovascular system: Insights from genetically modified mice. Circ. Res. 2003, 93, 907-916. [CrossRef]

239. Porter, V.A.; Bonev, A.D.; Knot, H.J.; Heppner, T.J.; Stevenson, A.S.; Kleppisch, T.; Lederer, W.J.; Nelson, M.T. Frequency modulation of $\mathrm{Ca}^{2+}$ sparks is involved in regulation of arterial diameter by cyclic nucleotides. Am. J. Physiol. Content 1998, 274, C1346-C1355. [CrossRef] [PubMed] 
240. Fukao, M.; Mason, H.S.; Britton, F.; Kenyon, J.; Horowitz, B.; Keef, K.D. Cyclic GMP-Dependent Protein Kinase Activates Cloned BKCa Channels Expressed in Mammalian Cells by Direct Phosphorylation at Serine 1072. J. Biol. Chem. 1999, $274,10927-10935$. [CrossRef]

241. $\mathrm{Hu}, \mathrm{X}$.-Q.; Zhang, L. Function and regulation of large conductance $\mathrm{Ca}^{2+}$-activated $\mathrm{K}^{+}$channel in vascular smooth muscle cells. Drug Discov. Today 2012, 17, 974-987. [CrossRef] [PubMed]

242. Khavandi, K.; Baylie, R.L.; Sugden, S.A.; Ahmed, M.; Csato, V.; Eaton, P.; Hill-Eubanks, D.C.; Bonev, A.D.; Nelson, M.T.; Greenstein, A.S. Pressure-Induced oxidative activation of PKG enables vasoregulation by $\mathrm{Ca}^{2+}$ sparks and BK channels. Sci. Signal. 2016, 9, ra100. [CrossRef] [PubMed]

243. Zhang, L.; Xiao, D.; Hu, X. Effect of cGMP on Pharmacomechanical Coupling in the Uterine Artery of Near-Term Pregnant Sheep. J. Pharmacol. Exp. Ther. 2008, 327, 425-431. [CrossRef]

244. Chen, J.; Ren, W.; Lin, L.; Zeng, S.; Huang, L.; Tang, J.; Bi, S.; Pan, J.; Chen, D.; Du, L. Abnormal cGMP-Dependent Protein Kinase I-Mediated Decidualization in Preeclampsia. Hypertens. Res. 2021, 44, 318-324. [CrossRef]

245. Singh, D.K.; Sarkar, J.; Raghavan, A.; Reddy, S.P.; Raj, J.U. Hypoxia Modulates the Expression of Leucine Zipper-Positive MYPT1 and its Interaction with Protein Kinase G and Rho Kinases in Pulmonary Arterial Smooth Muscle Cells. Pulm. Circ. 2011, 1, 487-498. [CrossRef]

246. Thorpe, R.B.; Hubbell, M.C.; Silpanisong, J.; Williams, J.M.; Pearce, W.J. Chronic hypoxia attenuates the vasodilator efficacy of protein kinase G in fetal and adult ovine cerebral arteries. Am. J. Physiol. Heart Circ. Physiol. 2017, 313, H207-H219. [CrossRef]

247. Takenaka, T.; Forster, H.; Epstein, M. Protein kinase $C$ and calcium channel activation as determinants of renal vasoconstriction by angiotensin II and endothelin. Circ. Res. 1993, 73, 743-750. [CrossRef]

248. Fallgren, B.; Bergstrand, H.; Edvinsson, L. Calcium influx and protein kinase C activation involved in uterine vasoconstriction in guinea pigs. Eur. J. Pharmacol. 1989, 170, 61-67. [CrossRef]

249. Bonev, A.D.; Jaggar, J.H.; Rubart, M.; Nelson, M.T. Activators of protein kinase C decrease Ca ${ }^{2+}$ spark frequency in smooth muscle cells from cerebral arteries. Am. J. Physiol. Content 1997, 273, C2090-C2095. [CrossRef] [PubMed]

250. Magness, R.R.; Rosenfeld, C.R.; Carr, B.R. Protein kinase $C$ in uterine and systemic arteries during ovarian cycle and pregnancy. Am. J. Physiol. Metab. 1991, 260, E464-E470. [CrossRef] [PubMed]

251. Kanashiro, C.A.; Cockrell, K.L.; Alexander, B.T.; Granger, J.P.; Khalil, R.A. Pregnancy-associated reduction in vascular protein kinase C activity rebounds during inhibition of NO synthesis. Am. J. Physiol. Integr. Comp. Physiol. 2000, 278, R295-R303. [CrossRef]

252. Xiao, D.; Huang, X.; Yang, S.; Zhang, L. Direct chronic effect of steroid hormones in attenuating uterine arterial myogenic tone: Role of protein kinase c/extracellular signal-regulated kinase 1/2. Hypertension 2009, 54, 352-358. [CrossRef]

253. Goulopoulou, S.; Hannan, J.; Matsumoto, T.; Webb, R.C. Pregnancy reduces RhoA/Rho kinase and protein kinase C signaling pathways downstream of thromboxane receptor activation in the rat uterine artery. Am. J. Physiol. Heart Circ. Physiol. 2012, 302, H2477-H2488. [CrossRef]

254. Xiao, D.; Huang, X.; Longo, L.D.; Zhang, L. PKC Regulates $\alpha 1$-Adrenoceptor-Mediated Contractions and Baseline Ca ${ }^{2+}$ Sensitivity in the Uterine Arteries of Nonpregnant and Pregnant Sheep Acclimatized to High Altitude Hypoxia. High Alt. Med. Biol. 2010, 11, 153-161. [CrossRef] [PubMed]

255. Haller, H.; Hempel, A.; Homuth, V.; Mandelkow, A.; Busjahn, A.; Maasch, C.; Drab, M.; Lindschau, C.; Jupner, A.; Vetter, K.; et al. Endothelial-Cell permeability and protein kinase C in pre-eclampsia. Lancet 1998, 351, 945-949. [CrossRef]

256. Xiao, D.; Huang, X.; Zhang, L. Chronic Hypoxia Differentially Up-Regulates Protein Kinase C-Mediated Ovine Uterine Arterial Contraction via Actin Polymerization Signaling in Pregnancy1. Biol. Reprod. 2012, 87, 1-9. [CrossRef] [PubMed]

257. Ni, Y.; May, V.; Braas, K.; Osol, G. Pregnancy augments uteroplacental vascular endothelial growth factor gene expression and vasodilator effects. Am. J. Physiol. Content 1997, 273, H938-H944. [CrossRef] [PubMed]

258. Hoeben, A.; Landuyt, B.; Highley, M.S.; Wildiers, H.; Van Oosterom, A.T.; De Bruijn, E.A. Vascular Endothelial Growth Factor and Angiogenesis. Pharmacol. Rev. 2004, 56, 549-580. [CrossRef]

259. Ribatti, D. The discovery of the placental growth factor and its role in angiogenesis: A historical review. Angiogenesis 2008, 11, 215-221. [CrossRef]

260. Itoh, S.; Brawley, L.; Wheeler, T.; Anthony, F.W.; Poston, L.; Hanson, M.A. Vasodilation to Vascular Endothelial Growth Factor in the Uterine Artery of the Pregnant Rat Is Blunted by Low Dietary Protein Intake. Pediatr. Res. 2002, 51, 485-491. [CrossRef]

261. Osol, G.; Celia, G.; Gokina, N.I.; Barron, C.; Chien, E.; Mandala, M.; Luksha, L.; Kublickiene, K. Placental growth factor is a potent vasodilator of rat and human resistance arteries. Am. J. Physiol. Heart Circ. Physiol. 2008, 294, H1381-H1387. [CrossRef] [PubMed]

262. David, A.L.; Torondel, B.; Zachary, I.; Wigley, V.; Abi-Nader, K.; Mehta, V.; Buckley, S.M.; Cook, T.; Boyd, M.; Rodeck, C.H.; et al. Local delivery of VEGF adenovirus to the uterine artery increases vasorelaxation and uterine blood flow in the pregnant sheep. Gene Ther. 2008, 15, 1344-1350. [CrossRef]

263. Mehta, V.; Abi-Nader, K.N.; Peebles, D.M.; Benjamin, E.; Wigley, V.; Torondel, B.; Filippi, E.; Shaw, S.W.; Boyd, M.; Martin, J.; et al. Long-term increase in uterine blood flow is achieved by local overexpression of VEGF-A165 in the uterine arteries of pregnant sheep. Gene Ther. 2011, 19, 925-935. [CrossRef] [PubMed]

264. Mehta, V.; Abi-Nader, K.N.; Shangaris, P.; Shaw, S.W.; Filippi, E.; Benjamin, E.; Boyd, M.; Peebles, D.M.; Martin, J.; Zachary, I.; et al. Local over-expression of VEGF-DDeltaNDeltaC in the uterine arteries of pregnant sheep results in long-term changes in uterine artery contractility and angiogenesis. PLoS ONE 2014, 9, e100021. [CrossRef] [PubMed] 
265. Burke, S.D.; Zsengeller, Z.; Khankin, E.; Lo, A.S.; Rajakumar, A.; Dupont, J.J.; McCurley, A.; Moss, M.E.; Zhang, D.; Clark, C.D.; et al. Soluble fms-like tyrosine kinase 1 promotes angiotensin II sensitivity in preeclampsia. J. Clin. Investig. 2016, 126, 2561-2574. [CrossRef] [PubMed]

266. Storment, J.M.; Meyer, M.; Osol, G. Estrogen augments the vasodilatory effects of vascular endothelial growth factor in the uterine circulation of the rat. Am. J. Obstet. Gynecol. 2000, 183, 449-453. [CrossRef]

267. Grummer, M.A.; Sullivan, J.A.; Magness, R.R.; Bird, I.M. Vascular endothelial growth factor acts through novel, pregnancyenhanced receptor signalling pathways to stimulate endothelial nitric oxide synthase activity in uterine artery endothelial cells. Biochem. J. 2008, 417, 501-511. [CrossRef]

268. Zhang, H.-H.; Chen, J.C.; Sheibani, L.; Lechuga, T.J.; Chen, N.-B. Pregnancy Augments VEGF-Stimulated In Vitro Angiogenesis and Vasodilator (NO and H2S) Production in Human Uterine Artery Endothelial Cells. J. Clin. Endocrinol. Metab. 2017, 102, 2382-2393. [CrossRef]

269. Boeldt, D.S.; Grummer, M.A.; Magness, R.R.; Bird, I.M. Altered VEGF-stimulated Ca ${ }^{2+}$ signaling in part underlies pregnancyadapted eNOS activity in UAEC. J. Endocrinol. 2014, 223, 1-11. [CrossRef] [PubMed]

270. Espinoza, J.; Betancourt, A.; Belfort, M.A.; Shamshirsaz, A.A.; Fox, K.A.; Yallampalli, C. Placental growth factor blunts uterine artery responses to angiotensin II. BJOG Int. J. Obstet. Gynaecol. 2019, 126, 1058-1064. [CrossRef] [PubMed]

271. Levine, R.J.; Maynard, S.E.; Qian, C.; Lim, K.-H.; England, L.J.; Yu, K.F.; Schisterman, E.; Thadhani, R.; Sachs, B.P.; Epstein, F.H.; et al. Circulating Angiogenic Factors and the Risk of Preeclampsia. N. Engl. J. Med. 2004, 350, 672-683. [CrossRef]

272. Ahmad, S.; Ahmed, A. Elevated Placental Soluble Vascular Endothelial Growth Factor Receptor-1 Inhibits Angiogenesis in Preeclampsia. Circ. Res. 2004, 95, 884-891. [CrossRef]

273. Shibata, E.; Rajakumar, A.; Powers, R.W.; Larkin, R.W.; Gilmour, C.; Bodnar, L.M.; Crombleholme, W.R.; Ness, R.B.; Roberts, J.M.; Hubel, C.A. Soluble fms-Like Tyrosine Kinase 1 Is Increased in Preeclampsia but Not in Normotensive Pregnancies with Smallfor-Gestational-Age Neonates: Relationship to Circulating Placental Growth Factor. J. Clin. Endocrinol. Metab. 2005, 90, 4895-4903. [CrossRef] [PubMed]

274. Sahay, A.S.; Patil, V.V.; Sundrani, D.P.; Joshi, A.A.; Wagh, G.N.; Gupte, S.A.; Joshi, S.R. A longitudinal study of circulating angiogenic and antiangiogenic factors and AT1-AA levels in preeclampsia. Hypertens. Res. 2014, 37, 753-758. [CrossRef]

275. Palmer, K.; Kaitu'U-Lino, T.J.; Hastie, R.; Hannan, N.J.; Ye, L.; Binder, N.; Cannon, P.; Tuohey, L.; Johns, T.; Shub, A.; et al. Placental-Specific sFLT-1 e15a Protein Is Increased in Preeclampsia, Antagonizes Vascular Endothelial Growth Factor Signaling, and Has Antiangiogenic Activity. Hypertension 2015, 66, 1251-1259. [CrossRef] [PubMed]

276. Munaut, C.; Lorquet, S.; Pequeux, C.; Blacher, S.; Berndt, S.; Frankenne, F.; Foidart, J.-M. Hypoxia is responsible for soluble vascular endothelial growth factor receptor-1 (VEGFR-1) but not for soluble endoglin induction in villous trophoblast. Hum. Reprod. 2008, 23, 1407-1415. [CrossRef] [PubMed]

277. Nevo, O.; Soleymanlou, N.; Wu, Y.; Xu, J.; Kingdom, J.; Many, A.; Zamudio, S.; Caniggia, I. Increased expression of sFlt-1 in in vivo and in vitro models of human placental hypoxia is mediated by HIF-1. Am. J. Physiol. Integr. Comp. Physiol. 2006, 291, R1085-R1093. [CrossRef]

278. Sasagawa, T.; Nagamatsu, T.; Morita, K.; Mimura, N.; Iriyama, T.; Fujii, T.; Shibuya, M. HIF-2 $\alpha$, but not HIF-1 $\alpha$, mediates hypoxia-induced up-regulation of Flt-1 gene expression in placental trophoblasts. Sci. Rep. 2018, 8, 17375. [CrossRef]

279. Kendall, R.L.; Thomas, K.A. Inhibition of vascular endothelial cell growth factor activity by an endogenously encoded soluble receptor. Proc. Natl. Acad. Sci. USA 1993, 90, 10705-10709. [CrossRef]

280. Maynard, S.E.; Min, J.-Y.; Merchan, J.; Lim, K.-H.; Li, J.; Mondal, S.; Libermann, T.; Morgan, J.P.; Sellke, F.W.; Stillman, I.E.; et al. Excess placental soluble fms-like tyrosine kinase 1 (sFlt1) may contribute to endothelial dysfunction, hypertension, and proteinuria in preeclampsia. J. Clin. Investig. 2003, 111, 649-658. [CrossRef]

281. Baker, P.; Krasnow, J.; Roberts, J.M.; Yeo, K.-T. Elevated serum levels of vascular endothelial growth factor in patients with preeclampsia. Obstet. Gynecol. 1995, 86, 815-821. [CrossRef]

282. Bosio, P.M.; Wheeler, T.; Anthony, F.; Conroy, R.; O’Herlihy, C.; McKenna, P. Maternal plasma vascular endothelial growth factor concentrations in normal and hypertensive pregnancies and their relationship to peripheral vascular resistance. Am. J. Obstet. Gynecol. 2001, 184, 146-152. [CrossRef]

283. McKeeman, G.C.; Ardill, J.E.; Caldwell, C.M.; Hunter, A.J.; McClure, N. Soluble vascular endothelial growth factor receptor-1 (sFlt-1) is increased throughout gestation in patients who have preeclampsia develop. Am. J. Obstet. Gynecol. 2004, 191, 1240-1246. [CrossRef] [PubMed]

284. Sanchez-Aranguren, L.; Espinosa-González, C.T.; González-Ortiz, L.M.; Sanabria-Barrera, S.M.; Riaño-Medina, C.E.; Nuñez, A.F.; Ahmed, A.; Vasquez-Vivar, J.; López, M. Soluble Fms-Like Tyrosine Kinase-1 Alters Cellular Metabolism and Mitochondrial Bioenergetics in Preeclampsia. Front. Physiol. 2018, 9, 83. [CrossRef] [PubMed]

285. Murphy, S.R.; LaMarca, B.B.D.; Cockrell, K.; Granger, J.P. Role of Endothelin in Mediating Soluble fms-Like Tyrosine Kinase 1-Induced Hypertension in Pregnant Rats. Hypertension 2010, 55, 394-398. [CrossRef]

286. Wang, Y.; Walsh, S.W. TNF alpha concentrations and mRNA expression are increased in preeclamptic placentas. J. Reprod. Immunol. 1996, 32, 157-169. [CrossRef]

287. Rinehart, B.K.; Terrone, D.A.; Lagoo-Deenadayalan, S.; Barber, W.H.; Hale, E.A.; Martin, J.N., Jr.; Bennett, W.A. Expression of the placental cytokines tumor necrosis factor alpha, interleukin 1beta, and interleukin 10 is increased in preeclampsia. Am. J. Obstet. Gynecol. 1999, 181, 915-920. [CrossRef] 
288. Benyo, D.F.; Smárason, A.; Redman, C.W.G.; Sims, C.; Conrad, K.P. Expression of Inflammatory Cytokines in Placentas from Women with Preeclampsia1. J. Clin. Endocrinol. Metab. 2001, 86, 2505-2512. [CrossRef] [PubMed]

289. Conrad, K.P.; Miles, T.M.; Benyo, D.F. Circulating Levels of Immunoreactive Cytokines in Women with Preeclampsia. Am. J. Reprod. Immunol. 1998, 40, 102-111. [CrossRef]

290. Peraçoli, J.C.; Rudge, M.V.C.; Peracoli, M.T. Tumor Necrosis Factor-alpha in Gestation and Puerperium of Women with Gestational Hypertension and Pre-eclampsia. Am. J. Reprod. Immunol. 2007, 57, 177-185. [CrossRef] [PubMed]

291. Sharma, A.; Satyam, A.; Sharma, J.B. Leptin, IL-10 and Inflammatory Markers (TNF-? IL-6 and IL-8) in Pre-Eclamptic, Normotensive Pregnant and Healthy Non-Pregnant Women. Am. J. Reprod. Immunol. 2007, 58, 21-30. [CrossRef]

292. Lau, S.Y.; Guild, S.-J.; Barrett, C.; Chen, Q.; McCowan, L.; Jordan, V.; Chamley, L. Tumor Necrosis Factor-Alpha, Interleukin-6, and Interleukin-10 Levels are Altered in Preeclampsia: A Systematic Review and Meta-Analysis. Am. J. Reprod. Immunol. 2013, 70, 412-427. [CrossRef]

293. Benyo, D.F.; Miles, T.M.; Conrad, K.P. Hypoxia Stimulates Cytokine Production by Villous Explants from the Human Placenta1. J. Clin. Endocrinol. Metab. 1997, 82, 1582-1588. [CrossRef]

294. Hung, T.H.; Charnock-Jones, D.S.; Skepper, J.N.; Burton, G.J. Secretion of tumor necrosis factor-alpha from human placental tissues induced by hypoxia-reoxygenation causes endothelial cell activation in vitro: A potential mediator of the inflammatory response in preeclampsia. Am. J. Pathol. 2004, 164, 1049-1061. [CrossRef]

295. Corda, S.; LaPlace, C.; Vicaut, E.; Duranteau, J. Rapid Reactive Oxygen Species Production by Mitochondria in Endothelial Cells Exposed to Tumor Necrosis Factor- $\alpha$ Is Mediated by Ceramide. Am. J. Respir. Cell Mol. Biol. 2001, 24, 762-768. [CrossRef] [PubMed]

296. Lai, P.F.; Mohamed, F.; Monge, J.C.; Stewart, D.J. Downregulation of eNOS mRNA expression by TNFalpha: Identification and functional characterization of RNA-protein interactions in the 3'UTR. Cardiovasc Res. 2003, 59, 160-168. [CrossRef]

297. Yan, G.; You, B.; Chen, S.-P.; Liao, J.K.; Sun, J. Tumor Necrosis Factor- $\alpha$ Downregulates Endothelial Nitric Oxide Synthase mRNA Stability via Translation Elongation Factor 1- $\alpha$ 1. Circ. Res. 2008, 103, 591-597. [CrossRef] [PubMed]

298. Yi, F.-X.; Boeldt, D.S.; Gifford, S.M.; Sullivan, J.A.; Grummer, M.A.; Magness, R.R.; Bird, I.M. Pregnancy Enhances Sustained Ca ${ }^{2+}$ Bursts and Endothelial Nitric Oxide Synthase Activation in Ovine Uterine Artery Endothelial Cells Through Increased Connexin 43 Function1. Biol. Reprod. 2010, 82, 66-75. [CrossRef]

299. Ampey, A.C.; Boeldt, D.S.; Clemente, L.; Grummer, M.A.; Yi, F.; Magness, R.R.; Bird, I.M. TNF-alpha inhibits pregnancy-adapted $\mathrm{Ca}^{2+}$ signaling in uterine artery endothelial cells. Mol. Cell. Endocrinol. 2019, 488, 14-24. [CrossRef]

300. Lamarca, B.B.D.; Cockrell, K.; Sullivan, E.; Bennett, W.; Granger, J.P. Role of Endothelin in Mediating Tumor Necrosis FactorInduced Hypertension in Pregnant Rats. Hypertension 2005, 46, 82-86. [CrossRef] [PubMed]

301. Sunderland, N.S.; Thomson, S.E.; Heffernan, S.J.; Lim, S.; Thompson, J.; Ogle, R.; McKenzie, P.; Kirwan, P.J.; Makris, A.; Hennessy, A. Tumor necrosis factor $\alpha$ induces a model of preeclampsia in pregnant baboons (Papio hamadryas). Cytokine 2011, 56, 192-199. [CrossRef]

302. Badran, M.; Abuyassin, B.; Ayas, N.; Laher, I. Intermittent hypoxia impairs uterine artery function in pregnant mice. J. Physiol. 2019, 597, 2639-2650. [CrossRef] [PubMed]

303. Small, H.Y.; Nosalski, R.; Morgan, H.; Beattie, E.; Guzik, T.J.; Graham, D.; Delles, C. Role of Tumor Necrosis Factor- $\alpha$ and Natural Killer Cells in Uterine Artery Function and Pregnancy Outcome in the Stroke-Prone Spontaneously Hypertensive Rat. Hypertension 2016, 68, 1298-1307. [CrossRef]

304. Travis, O.K.; Tardo, G.A.; Giachelli, C.; Siddiq, S.; Nguyen, H.T.; Crosby, M.T.; Johnson, T.; Brown, A.K.; Williams, J.M.; Cornelius, D.C. Tumor Necrosis Factor-Alpha Blockade Improves Uterine Artery Resistance, Maternal Blood Pressure, and Fetal Growth in Placental Ischemic Rats. Pregnancy Hypertens. 2021, 25, 39-47. [CrossRef] [PubMed]

305. Yang, X.; Wang, F.; Chang, H.; Zhang, S.; Yang, L.; Wang, X.; Cheng, X.; Zhang, M.; Ma, X.L.; Liu, H. Autoantibody against AT1 receptor from preeclamptic patients induces vasoconstriction through angiotensin receptor activation. J. Hypertens. 2008, 26, 1629-1635. [CrossRef]

306. Wallukat, G.; Homuth, V.; Fischer, T.; Lindschau, C.; Horstkamp, B.; Jüpner, A.; Baur, E.; Nissen, E.; Vetter, K.; Neichel, D.; et al. Patients with preeclampsia develop agonistic autoantibodies against the angiotensin AT1 receptor. J. Clin. Investig. 1999, 103, 945-952. [CrossRef]

307. Wallukat, G.; Neichel, D.; Nissen, E.; Homuth, V.; Luft, F. Agonistic autoantibodies directed against the angiotensin II AT1 receptor in patients with preeclampsia. Can. J. Physiol. Pharmacol. 2003, 81, 79-83. [CrossRef]

308. Walther, T.; Wallukat, G.; Jank, A.; Bartel, S.; Schultheiss, H.-P.; Faber, R.; Stepan, H. Angiotensin II Type 1 Receptor Agonistic Antibodies Reflect Fundamental Alterations in the Uteroplacental Vasculature. Hypertension 2005, 46, 1275-1279. [CrossRef] [PubMed]

309. Faulkner, J.L.; Amaral, L.M.; Cornelius, D.; Cunningham, M.W.; Ibrahim, T.; Heep, A.; Campbell, N.; Usry, N.; Wallace, K.; Herse, F.; et al. Vitamin D supplementation reduces some AT1-AA-induced downstream targets implicated in preeclampsia including hypertension. Am. J. Physiol. Integr. Comp. Physiol. 2017, 312, R125-R131. [CrossRef] [PubMed]

310. Cunningham, M.W.; Castillo, J.; Ibrahim, T.; Cornelius, D.C.; Campbell, N.; Amaral, L.; Vaka, V.R.; Usry, N.; Williams, J.M.; LaMarca, B. AT1-AA (Angiotensin II Type 1 Receptor Agonistic Autoantibody) Blockade Prevents Preeclamptic Symptoms in Placental Ischemic Rats. Hypertension 2018, 71, 886-893. [CrossRef] [PubMed] 
311. Deer, E.; Vaka, V.R.; McMaster, K.M.; Wallace, K.; Cornelius, D.C.; Amaral, L.M.; Cunningham, M.W.; LaMarca, B. Vascular endothelial mitochondrial oxidative stress in response to preeclampsia: A role for angiotension II type 1 autoantibodies. Am. J. Obstet. Gynecol. MFM 2021, 3, 100275. [CrossRef] [PubMed]

312. Vaka, V.R.; Cunningham, M.W.; Deer, E.; Franks, M.; Ibrahim, T.; Amaral, L.M.; Usry, N.; Cornelius, D.C.; Dechend, R.; Wallukat, G.; et al. Blockade of endogenous angiotensin II type I receptor agonistic autoantibody activity improves mitochondrial reactive oxygen species and hypertension in a rat model of preeclampsia. Am. J. Physiol. Integr. Comp. Physiol. 2020, 318, R256-R262. [CrossRef] [PubMed]

313. Wang, P.; Zhang, S.; Ren, J.; Yan, L.; Bai, L.; Wang, L.; Bian, J.; Yin, X.; Liu, H. The inhibitory effect of BKCa channels induced by autoantibodies against angiotensin II type 1 receptor is independent of AT1R. Acta Biochim. Biophys. Sin. 2018, 50, 560-566. [CrossRef] [PubMed] 